Check for updates

Cite this: New J. Chem., 2018, 42,8661

Received 10th December 2017 Accepted 4th April 2018

DOI: $10.1039 / c 7 n j 04888 b$

rsc.li/njc

\section{Influence of ancillary ligands on the photophysical properties of cyclometalated organoplatinum(II) complexes $\dagger$}

\author{
Mozhgan Samandar Sangari, ${ }^{a}$ Mohsen Golbon Haghighi, (D) *b \\ S. Masoud Nabavizadeh, (iD ${ }^{a}$ Arno Pfitzner (D) ${ }^{c}$ and Mehdi Rashidi*a
}

\begin{abstract}
Three series of cyclometalated organoplatinum(॥) complexes [Pt(p- $\left.\left.\mathrm{MeC}_{6} \mathrm{H}_{4}\right)(\mathrm{bhq})(\mathrm{L})\right]$, in which bhq is

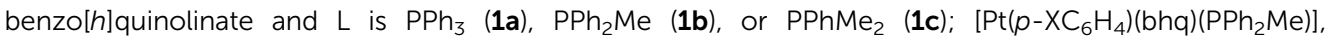
in which $X$ is $\mathrm{H}(\mathbf{2} \mathbf{a}), F(\mathbf{2 b}),{ }^{t} \mathrm{Bu}(\mathbf{2 c}), \mathrm{OMe}(\mathbf{2 d})$, or $\mathrm{Me}(\mathbf{2 e}=\mathbf{1} \mathbf{b})$; and $\left[\mathrm{Pt}(\mathrm{bhq}) X\left(\mathrm{PPh}_{2} \mathrm{Me}\right)\right]$, in which $X$ is $\mathrm{CF}_{3} \mathrm{CO}_{2}(\mathbf{3 a}), \mathrm{Cl}(\mathbf{3 b})$, or I (3c) were synthesized and fully characterized using multinuclear $\left({ }^{1} \mathrm{H}\right.$ and $\left.{ }^{31} \mathrm{P}\right)$ NMR spectroscopy and elemental analysis. Typical complexes $\left[\mathrm{Pt}\left(p-\mathrm{MeC}_{6} \mathrm{H}_{4}\right)(\mathrm{bhq})(\mathrm{PPhMe})\right], 1 \mathbf{c}$, $\left[\mathrm{Pt}\left(p-\mathrm{MeC}_{6} \mathrm{H}_{4}\right)(\mathrm{bhq})\left(\mathrm{PPh}_{2} \mathrm{Me}\right)\right], \mathbf{2 e}$, and $\left[\mathrm{Pt}(\mathrm{bhq}) \mathrm{Cl}\left(\mathrm{PPh}_{2} \mathrm{Me}\right)\right], \mathbf{3 b}$, were further characterized by single crystal X-ray crystallography. The photophysical properties of all the complexes were studied and the influence of changing the ancillary ligands and substituents on their luminescence properties were investigated and the assignments were confirmed by TD-DFT calculations.
\end{abstract}

\section{Introduction}

Significant research efforts have been focused on the photophysical properties of luminescent square planar platinum complexes. Among them, cyclometalated platinum complexes have attracted much attention as phosphorescent emitters in organic light emitting diodes (OLEDs) and luminescent probes for bioimaging. ${ }^{1-3}$ These applications in optical technologies are based on the strong luminescence displayed by such materials and the wide tunability of the emission properties by chemical modifications of the molecular structures. ${ }^{4,5}$

In mixed-ligand $\left[\mathrm{Pt}^{(}\left(\mathrm{C}^{\wedge} \mathrm{N}\right) \mathrm{XY}\right]$ complexes, the strong ligandfield influence of the aromatic carbon donor of $\mathrm{C}^{\wedge} \mathrm{N}$ where $\left(\mathrm{C}^{\wedge} \mathrm{N}\right)$ is the ortho-C-deprotonated form of 2-phenylpyridine (ppy-) and benzo[h]quinoline (bhq-) combined with the possibility of $\pi$-back-donation into the metallocycle yields generally high-lying MC states. ${ }^{6,7}$ Thus, the luminescence of these complexes originates from the lowest ligand-centered triplet state $\left({ }^{3} \mathrm{LC}\right)$ that is perturbed by admixtures with higher lying metalto-ligand charge-transfer singlet and triplet $\left({ }^{1,3} \mathrm{MLCT}\right)$ states.

\footnotetext{
${ }^{a}$ Professor Rashidi Laboratory of Organometallic Chemistry, Department of Chemistry, College of Sciences, Shiraz University, Shiraz 71467-13565, Iran

${ }^{b}$ Department of Chemistry, Shahid Beheshti University, Evin, Tehran 19839-69411, Iran. E-mail: m_golbon@sbu.ac.ir

${ }^{c}$ Institut für Anorganische Chemie, Universität Regensburg, Universitätstarsse 31, Regensburg D-93053, Germany

$\dagger$ Electronic supplementary information (ESI) available. CCDC 1513088-1513090. For ESI and crystallographic data in CIF or other electronic format see DOI: 10.1039/c7nj04888b
}

Increasing the covalency of metal-ligand bonds eventuates to increase the MLCT character of the excited states. ${ }^{8}$

Unlike bis-cyclometalated $\mathrm{Pt}(\mathrm{II})$ complexes, which can be prepared by using lithiated organic ligands, ${ }^{9}$ the $\left[\operatorname{Pt}\left(\mathrm{C}^{\wedge} \mathrm{N}\right) \mathrm{XY}\right]$ complexes, where $\mathrm{X}$ and $\mathrm{Y}$ represent monodentate and bidentate ligands with different donor and acceptor properties, are readily formed by the substitution of the labile leaving groups such as $\mathrm{SMe}_{2}{ }^{6,10}$ and $\mathrm{DMSO}^{11,12}$ in the parent $\left[\mathrm{Pt}\left(\mathrm{C}^{\wedge} \mathrm{N}\right) \operatorname{Ar}(\mathrm{S})\right]$ complexes with various $\mathrm{X}$ and $\mathrm{Y}$ reagants.

In the present paper, we invesitigated the photophysical properties of three series of cyclometalated organoplatinum(II) complexes, by modifying different kinds of ancillary ligands and changing the substituents on them and the effects of each part on their luminescence properties were studied. For better understanding and interpretation of the relationship between luminescence properties and structural details, DFT and TD-DFT calculations were employed on electronic transitions and geometrical structures.

\section{Experimental}

\subsection{General remarks}

The NMR spectra were recorded on a Bruker Avance DPX $250 \mathrm{MHz}$ spectrometer $\left({ }^{1} \mathrm{H}\right)$, a Bruker Avance DRX $400 \mathrm{MHz}$ spectrometer $\left({ }^{1} \mathrm{H}\right.$ and $\left.{ }^{31} \mathrm{P}\right)$, or a Bruker Avance DRX $500 \mathrm{MHz}$ spectrometer $\left({ }^{1} \mathrm{H}\right.$ and $\left.{ }^{31} \mathrm{P}\right)$. The operating frequencies and references, respectively, are shown in parentheses as follows: ${ }^{1} \mathrm{H}\left(250 \mathrm{MHz}, 400 \mathrm{MHz}\right.$, or $500 \mathrm{MHz}$, TMS), ${ }^{31} \mathrm{P}(162 \mathrm{MHz}$ or $202 \mathrm{MHz}, 85 \% \mathrm{H}_{3} \mathrm{PO}_{4}$ ). The chemical shifts and coupling 
constants are in ppm and $\mathrm{Hz}$, respectively. The microanalyses were performed using a Thermofinigan Flash EA-1112 CHNSO rapid elemental analyzer. The UV-vis absorption spectra were carried out in a PerkinElmer Lambda 25 spectrophotometer in a cuvette with a $1 \mathrm{~cm}$ and/or $1 \mathrm{~mm}$ path length. The emission spectra were obtained on a PerkinElmer LS45 fluorescence spectrometer with the lifetimes measured in phosphorimeter mode. Absolute measurements of the photoluminescence quantum yield at ambient temperature under Ar were performed with a C9920202 (Hamamatsu Photonics) system equipped with a Spectralon ${ }^{\circledR}$ integrating sphere. The precursors $\left[\mathrm{Pt}\left(p-\mathrm{MeC}_{6} \mathrm{H}_{4}\right)(\mathrm{bhq})\left(\mathrm{SMe}_{2}\right)\right]$, in which bhq is benzo[ $h]$ quinolinate, ${ }^{13}\left[\mathrm{Pt}(\mathrm{bhq})\left(\mathrm{CF}_{3} \mathrm{CO}_{2}\right)\left(\mathrm{SMe}_{2}\right)\right],{ }^{14}$ $[\mathrm{Pt}(\mathrm{bhq}) \mathrm{Cl}(\mathrm{DMSO})],{ }^{15}$ and cis-[$\left[\mathrm{Pt}\left(p-\mathrm{XC}_{6} \mathrm{H}_{4}\right)_{2}\left(\mathrm{SMe}_{2}\right)_{2}\right],{ }^{16}$ were synthesized similar to literature methods. The complex [Pt(bhq)I(DMSO)] was prepared similar to ref. 17 by the reaction of [Pt(bhq)Cl(DMSO)] with 3 equiv. NaI in acetone. After stirring overnight, the solvent was evaporated and the residue was extracted by dichloromethane. The product was obtained by evaporation of the dichloromethane solution under reduced pressure and then washing the residue with diethyl ether $(2 \times 2 \mathrm{ml})$. Yield $82 \% ; \mathrm{C}_{15} \mathrm{H}_{14} \mathrm{INOSPt}$ : calcd C, 31.1; H, 2.4; N, 2.4; found: C, 30.5; H, 2.2; N, 2.3. NMR data in $\mathrm{CDCl}_{3}: \delta\left({ }^{1} \mathrm{H}\right)=4.00\left(\mathrm{~s},{ }^{3} J_{\mathrm{PtH}}=24.6 \mathrm{~Hz}, \mathrm{DMSO}\right)$; aromatic protons: $6.8-9.5$.

\subsection{Synthesis of the complexes}

$\left[\mathbf{P t}\left(\boldsymbol{p}-\mathbf{M e C}_{6} \mathbf{H}_{4}\right)(\mathbf{b h q})\left(\mathbf{P P h}_{3}\right)\right]$, 1a. cis- $\left[\mathrm{Pt}\left(p-\mathrm{MeC}_{6} \mathrm{H}_{4}\right)_{2}\left(\mathrm{SMe}_{2}\right)_{2}\right]$ (150 $\mathrm{mg}, 0.3 \mathrm{mmol})$ was dissolved in acetone $(30 \mathrm{~mL})$ and benzo[h]quinoline (55 mg, $0.3 \mathrm{mmol}$ ) was added. The reaction mixture was refluxed for $12 \mathrm{~h}$. After cooling, 1.05 equiv. $\mathrm{PPh}_{3}$ was added to the mixture and stirred at RT for $2 \mathrm{~h}$. The solvent was removed under reduced pressure and the residue was washed with cold diethyl ether $(2 \times 2 \mathrm{ml})$. The yellowish green solid was dried under vacuum. Yield: $168 \mathrm{mg}, 77 \%$. Anal. calcd for $\mathrm{C}_{38} \mathrm{H}_{30} \mathrm{NPPt}$ C, 62.8, H, 4.2, N, 1.9; found: $\mathrm{C}, 62.3, \mathrm{H}, 4.0, \mathrm{~N}, 2.0$. NMR data in $\mathrm{CDCl}_{3}: \delta\left({ }^{1} \mathrm{H}\right)=2.14\left(\mathrm{~s}, 3 \mathrm{H}, \mathrm{CH}_{3}\right.$ of $\left.p-\mathrm{MeC}_{6} \mathrm{H}_{4}\right)$, aromatic protons: 6.4-8.2; $\delta\left({ }^{31} \mathrm{P}\right)=30.6\left(\mathrm{~s},{ }^{1} J_{\mathrm{PtP}}=2107 \mathrm{~Hz}, \mathrm{P}\right.$ trans to $\mathrm{C}$ of bhq in $\left.\mathrm{PPh}_{3}\right)$.

The following complexes were prepared similarly by using the appropriate starting complexes cis- $\left[\mathrm{Pt}\left(p-\mathrm{XC}_{6} \mathrm{H}_{4}\right)_{2}\left(\mathrm{SMe}_{2}\right)_{2}\right]$ and the related phosphine ligands $\mathrm{PPh}_{2} \mathrm{Me}$ or $\mathrm{PPhMe}_{2}$.

$\left[\mathbf{P t}\left(p-\mathbf{M e C}_{6} \mathbf{H}_{4}\right)(\mathbf{b h q})\left(\mathbf{P P h}_{2} \mathbf{M e}\right)\right], \mathbf{1 b}(=2 \mathrm{e})$. Yield: $82 \%$. Anal. calcd for $\mathrm{C}_{33} \mathrm{H}_{28} \mathrm{NPPt}$ : C, 59.6, H, 4.3, N, 2.1; found: C, 59.4, H, 5.0, N, 1.9. NMR data in $\mathrm{CDCl}_{3}: \delta\left({ }^{1} \mathrm{H}\right)=1.49\left(\mathrm{~d},{ }^{2} J_{\mathrm{PH}}=8.9 \mathrm{~Hz}\right.$, ${ }^{3} J_{\mathrm{PtH}}=27.0 \mathrm{~Hz}, 3 \mathrm{H}, \mathrm{CH}_{3}$ of $\left.\mathrm{PPh}_{2} \mathrm{Me}\right), 2.28\left(\mathrm{~s}, 3 \mathrm{H}, \mathrm{CH}_{3}\right.$ of $p$ - $\left.\mathrm{MeC}_{6} \mathrm{H}_{4}\right)$, aromatic protons: $6.8-8.2 ; \delta\left({ }^{31} \mathrm{P}\right)=13.5\left(\mathrm{~s},{ }^{1} J_{\mathrm{PtP}}=\right.$ $2061 \mathrm{~Hz}, \mathrm{P}$ trans to $\mathrm{C}$ of bhq in $\left.\mathrm{PPh}_{2} \mathrm{Me}\right)$.

$\left[\operatorname{Pt}\left(p-\mathbf{M e C}_{6} \mathbf{H}_{4}\right)(\mathbf{b h q})(\mathbf{P P h M e})\right]$, 1c. Yield: $71 \%$. Anal. calcd for $\mathrm{C}_{28} \mathrm{H}_{26} \mathrm{NPPt}$ : C, 55.8, H, 4.4, N, 2.3; found: C, 56.2, H, 4.2, N, 2.7. NMR data in $\mathrm{CDCl}_{3}: \delta\left({ }^{1} \mathrm{H}\right)=1.54\left(\mathrm{~d},{ }^{2} J_{\mathrm{PH}}=8.2 \mathrm{~Hz},{ }^{3} J_{\mathrm{PtH}}=\right.$ $23.5 \mathrm{~Hz}, 6 \mathrm{H}, \mathrm{CH}_{3}$ of $\left.\mathrm{PPhMe}_{2}\right), 2.32\left(\mathrm{~s}, 3 \mathrm{H}, \mathrm{CH}_{3}\right.$ of $\left.p-\mathrm{MeC}_{6} \mathrm{H}_{4}\right)$, aromatic protons: $6.9-8.2 ; \delta\left({ }^{31} \mathrm{P}\right)=-1.3\left(\mathrm{~s},{ }^{1} J_{\mathrm{PtP}}=2010 \mathrm{~Hz}\right.$, $\mathrm{P}$ trans to $\mathrm{C}$ of bhq in $\left.\mathrm{PPhMe}_{2}\right)$.

[Pt $\left.\left(\mathbf{C}_{6} \mathbf{H}_{5}\right)(\mathbf{b h q})\left(\mathbf{P P h}_{2} \mathbf{M e}\right)\right]$, 2a. Yield: $85 \%$. Anal. calcd for $\mathrm{C}_{32} \mathrm{H}_{26} \mathrm{NPPt}$ C, 59.1, H, 4.0, N, 2.2; found: C, 58.4, H, 4.3, N, 2.5. NMR data in $\mathrm{CDCl}_{3}: \delta\left({ }^{1} \mathrm{H}\right)=1.50\left(\mathrm{~d},{ }^{2} J_{\mathrm{PH}}=8.7 \mathrm{~Hz},{ }^{3} J_{\mathrm{PtH}}=\right.$ $27.0 \mathrm{~Hz}, 3 \mathrm{H}, \mathrm{CH}_{3}$ of $\mathrm{PPh}_{2} \mathrm{Me}$ ), aromatic protons: 6.9-8.2; $\delta\left({ }^{31} \mathrm{P}\right)=13.5\left(\mathrm{~s},{ }^{1} J_{\mathrm{PtP}}=2060 \mathrm{~Hz}, \mathrm{P}\right.$ trans to $\mathrm{C}$ of bhq in $\left.\mathrm{PPh}_{2} \mathrm{Me}\right)$.
$\left[\mathbf{P t}\left(\boldsymbol{p}-\mathrm{FC}_{6} \mathbf{H}_{4}\right)(\mathbf{b h q})\left(\mathbf{P P h}_{2} \mathbf{M e}\right)\right], 2$ b. Yield: $61 \%$. Anal. calcd for $\mathrm{C}_{32} \mathrm{H}_{25}$ NFPPt: C, 57.5, H, 3.7, N, 2.1; found: C, 56.6, H, 3.1, N, 1.7. NMR data in $\mathrm{CDCl}_{3}: \delta\left({ }^{1} \mathrm{H}\right)=2.51\left(\mathrm{~d},{ }^{2} J_{\mathrm{PH}}=10.9 \mathrm{~Hz},{ }^{3} J_{\mathrm{PtH}}=\right.$ $36.1 \mathrm{~Hz}, 3 \mathrm{H}, \mathrm{CH}_{3}$ of $\mathrm{PPh}_{2} \mathrm{Me}$ ), 10.33 (br. t, ${ }^{3} J_{\mathrm{HH}} \approx{ }^{4} J_{\mathrm{PH}}=4.7 \mathrm{~Hz}$, $1 \mathrm{H}, \mathrm{H}^{8}$ of bhq), other aromatic protons: $6.7-8.4 ; \delta\left({ }^{31} \mathrm{P}\right)=14.8$ $\left(\mathrm{s},{ }^{1} J_{\mathrm{PtP}}=2197 \mathrm{~Hz}, \mathrm{P}\right.$ trans to $\mathrm{C}$ of bhq in $\left.\mathrm{PPh}_{2} \mathrm{Me}\right)$.

$\left[\mathbf{P t}\left(p-{ }^{t} \mathrm{BuC}_{6} \mathrm{H}_{4}\right)(\mathbf{b h q})\left(\mathbf{P P h}_{2} \mathrm{Me}\right)\right]$, 2c. Yield: $68 \%$. Anal. calcd for $\mathrm{C}_{36} \mathrm{H}_{34} \mathrm{NPPt}$ : C, 61.2, H, 4.9, N, 1.98; found: C, 60.6, H, 4.6, $\mathrm{N}$, 2.1. NMR data in $\mathrm{CDCl}_{3}: \delta\left({ }^{1} \mathrm{H}\right)=1.31\left(\mathrm{~s}, 9 \mathrm{H}, \mathrm{C}\left(\mathrm{CH}_{3}\right)_{3}\right.$ of $\left.p-{ }^{t} \mathrm{BuC}_{6} \mathrm{H}_{4}\right), 1.47\left(\mathrm{~d},{ }^{2} J_{\mathrm{PH}}=8.7 \mathrm{~Hz},{ }^{3} J_{\mathrm{PtH}}=26.3 \mathrm{~Hz}, 3 \mathrm{H}, \mathrm{CH}_{3}\right.$ of $\left.\mathrm{PPh}_{2} \mathrm{Me}\right)$, aromatic protons: $6.9-8.2 ; \delta\left({ }^{31} \mathrm{P}\right)=14.0\left(\mathrm{~s},{ }^{1} J_{\mathrm{PtP}}=2063 \mathrm{~Hz}\right.$, $\mathrm{P}$ trans to $\mathrm{C}$ of bhq in $\left.\mathrm{PPh}_{2} \mathrm{Me}\right)$.

$\left[\mathbf{P t}\left(p-\mathrm{MeOC}_{6} \mathbf{H}_{4}\right)(\mathbf{b h q})\left(\mathbf{P P h}_{2} \mathbf{M e}\right)\right], 2 d$. Yield: $79 \%$. Anal. calcd for $\mathrm{C}_{32} \mathrm{H}_{28}$ NOPPt: C, 58.2, H, 4.1, N, 2.1; found: C, 58.0, H, 4.3, $\mathrm{N}, 1.9$. NMR data in $\mathrm{CDCl}_{3}: \delta\left({ }^{1} \mathrm{H}\right)=1.49\left(\mathrm{~d},{ }^{2} J_{\mathrm{PH}}=8.7 \mathrm{~Hz},{ }^{3} J_{\mathrm{PtH}}=\right.$ $26.5 \mathrm{~Hz}, 3 \mathrm{H}, \mathrm{CH}_{3}$ of $\mathrm{PPh}_{2} \mathrm{Me}$ ), $3.79\left(\mathrm{~s}, 3 \mathrm{H}, \mathrm{CH}_{3}\right.$ of $\left.p-\mathrm{MeOC}_{6} \mathrm{H}_{4}\right)$, aromatic protons: $6.6-8.2 ; \delta\left({ }^{31} \mathrm{P}\right)=13.6\left(\mathrm{~s},{ }^{1} J_{\mathrm{PtP}}=2044 \mathrm{~Hz}\right.$, $\mathrm{P}$ trans to $\mathrm{C}$ of bhq in $\left.\mathrm{PPh}_{2} \mathrm{Me}\right)$.

[Pt(bhq) $\left.\left(\mathbf{C F}_{3} \mathbf{C O}_{2}\right)\left(\mathbf{P P h}_{2} \mathbf{M e}\right)\right]$, 3a. To a solution of [Pt(bhq)$\left.\left(\mathrm{CF}_{3} \mathrm{CO}_{2}\right)\left(\mathrm{SMe}_{2}\right)\right]$ (55 mg, $\left.0.1 \mathrm{mmol}\right)$ in acetone $(15 \mathrm{ml})$ was added $\mathrm{PPh}_{2} \mathrm{Me}(19 \mu \mathrm{l}, 0.1 \mathrm{mmol})$. The mixture was stirred at RT for $2 \mathrm{~h}$. The solvent was removed under reduced pressure and the residue was washed with cold diethyl ether $(2 \times 2 \mathrm{ml})$. The yellow solid was dried under vacuum. Yield: $52 \mathrm{mg}, 76 \%$. Anal. calcd for $\mathrm{C}_{28} \mathrm{H}_{21} \mathrm{NO}_{2} \mathrm{~F}_{3}$ PPt: C, 49.0, $\mathrm{H}, 3.0, \mathrm{~N}, 2.0$; found: C, 48.6, $\mathrm{H}, 2.5, \mathrm{~N}, 2.3$. NMR data in $\mathrm{CDCl}_{3}: \delta\left({ }^{1} \mathrm{H}\right)=2.34\left(\mathrm{~d},{ }^{2} J_{\mathrm{PH}}=10.6 \mathrm{~Hz}\right.$, ${ }^{3} J_{\mathrm{PtH}}=40.4 \mathrm{~Hz}, 3 \mathrm{H}, \mathrm{CH}_{3}$ of $\left.\mathrm{PPh}_{2} \mathrm{Me}\right), 6.92\left(\mathrm{dd},{ }^{3} J_{\mathrm{HH}}=7.2 \mathrm{~Hz}\right.$, ${ }^{4} J_{\mathrm{PH}}=2.4 \mathrm{~Hz},{ }^{3} J_{\mathrm{PtH}} \approx 53 \mathrm{~Hz}, 1 \mathrm{H}, \mathrm{H}^{1}$ of bhq), 8.82 (br. $\mathrm{t},{ }^{3} J_{\mathrm{HH}} \approx$ ${ }^{4} J_{\mathrm{PH}}=4.5 \mathrm{~Hz}, 1 \mathrm{H}, \mathrm{H}^{8}$ of bhq), other aromatic protons: 7.0-8.0; $\delta\left({ }^{31} \mathrm{P}\right)=4.9\left(\mathrm{~s},{ }^{1} J_{\mathrm{PtP}}=4317 \mathrm{~Hz}, \mathrm{P}\right.$ trans to $\mathrm{N}$ of bhq in $\left.\mathrm{PPh}_{2} \mathrm{Me}\right)$.

$\left[\mathbf{P t}(\mathbf{b h q}) \mathbf{C l}\left(\mathbf{P P h}_{2} \mathbf{M e}\right)\right], 3 \mathbf{3 b}$. This compound was prepared similarly to complex 3a by using [Pt(bhq)Cl(DMSO)]. Yield: $82 \%$. Anal. calcd for $\mathrm{C}_{26} \mathrm{H}_{21}$ NPClPt: C, 51.3, H, 3.5, N, 2.3; found: C, 50.7, H, 3.1, N, 2.6. NMR data in $\mathrm{CDCl}_{3}: \delta\left({ }^{1} \mathrm{H}\right)=2.38\left(\mathrm{~d},{ }^{2} J_{\mathrm{PH}}=\right.$ $11.0 \mathrm{~Hz},{ }^{3} \mathrm{~J}_{\mathrm{PtH}}=33.9 \mathrm{~Hz}, 3 \mathrm{H}, \mathrm{CH}_{3}$ of $\left.\mathrm{PPh}_{2} \mathrm{Me}\right), 6.85\left(\mathrm{dd},{ }^{3} \mathrm{~J}_{\mathrm{HH}}=\right.$ $7.2 \mathrm{~Hz},{ }^{4} J_{\mathrm{PH}}=2.6 \mathrm{~Hz},{ }^{3} J_{\mathrm{PtH}} \approx 56 \mathrm{~Hz}, 1 \mathrm{H}, \mathrm{H}^{1}$ of bhq), 10.05 (br. t, ${ }^{3} J_{\mathrm{HH}} \approx{ }^{4} J_{\mathrm{PH}}=4.1 \mathrm{~Hz}, 1 \mathrm{H}, \mathrm{H}^{8}$ of $\mathrm{bhq}$ ), other aromatic protons: $6.9-8.4 ; \delta\left({ }^{31} \mathrm{P}\right)=4.9\left(\mathrm{~s},{ }^{1} J_{\mathrm{PtP}}=4252 \mathrm{~Hz}, \mathrm{P}\right.$ trans to $\mathrm{N}$ of bhq in $\left.\mathrm{PPh}_{2} \mathrm{Me}\right)$.

[Pt(bhq)I(PPh $\mathbf{M e})]$, 3c. Compound 3c was prepared similarly to complex 3a by using [Pt(bhq)I(DMSO)]. Yield: $66 \%$. Anal. calcd for $\mathrm{C}_{26} \mathrm{H}_{21}$ NOPPt: C, 44.6, H, 3.0, N, 2.0; found: $\mathrm{C}$, 44.1, H, 2.7, N, 2.1. NMR data in $\mathrm{CDCl}_{3}: \delta\left({ }^{1} \mathrm{H}\right)=2.69\left(\mathrm{~d},{ }^{2} J_{\mathrm{PH}}=\right.$ $10.6 \mathrm{~Hz},{ }^{3} \mathrm{~J}_{\mathrm{PtH}}=38.9 \mathrm{~Hz}, 3 \mathrm{H}, \mathrm{CH}_{3}$ of $\left.\mathrm{PPh}_{2} \mathrm{Me}\right), 6.85\left(\mathrm{dd},{ }^{3} \mathrm{~J}_{\mathrm{HH}}=\right.$ $7.3 \mathrm{~Hz},{ }^{4} J_{\mathrm{PH}}=3.8 \mathrm{~Hz},{ }^{3} J_{\mathrm{PtH}} \approx 57 \mathrm{~Hz}, 1 \mathrm{H}, \mathrm{H}^{1}$ of bhq), 10.72 (br. t, ${ }^{3} J_{\mathrm{HH}} \approx{ }^{4} J_{\mathrm{PH}}=4.8 \mathrm{~Hz}, 1 \mathrm{H}, \mathrm{H}^{8}$ of $\mathrm{bhq}$ ), other aromatic protons: 6.9-8.4; $\delta\left({ }^{31} \mathrm{P}\right)=3.7\left(\mathrm{~s},{ }^{1} J_{\mathrm{PtP}}=4184 \mathrm{~Hz}, \mathrm{P}\right.$ trans to $\mathrm{N}$ of bhq in $\mathrm{PPh}_{2} \mathrm{Me}$ ).

\subsection{Computational details}

Density functional calculations were performed with the program suite Gaussian $03^{18}$ using the B3LYP level of theory. The LANL2DZ basis set ${ }^{19}$ was chosen to describe Pt. The 6-31G(d) basis set was used for all other atoms. The geometries of the complexes under discussion were fully optimized by employing density functional theory without imposing any symmetry constraints. To evaluate 
Table 1 Crystal data and structure refinements for $\mathbf{1 c}, \mathbf{2 e}$ and $\mathbf{3 b}$ complexes

\begin{tabular}{|c|c|c|c|}
\hline & 1c & $2 e$ & $3 \mathbf{b}$ \\
\hline Empirical formula & $\mathrm{C}_{28} \mathrm{H}_{26} \mathrm{NPPt}$ & $\mathrm{C}_{33} \mathrm{H}_{28} \mathrm{NPPt}$ & $\mathrm{C}_{26} \mathrm{H}_{21} \mathrm{ClNPPt}$ \\
\hline Formula weight & 602.56 & 664.62 & 608.95 \\
\hline Temperature & $296.17(10) \mathrm{K}$ & $123.0 \mathrm{~K}$ & $293.0 \mathrm{~K}$ \\
\hline Wavelength & $1.54184 \AA$ & $0.71073 \AA$ & $1.54184 \AA$ \\
\hline Crystal system & Monoclinic & Triclinic & Monoclinic \\
\hline Space group & $P 2_{1} / c($ no. 14$)$ & $P \overline{1}$ (no. 2 ) & $P 2_{1} / c($ no. 14$)$ \\
\hline \multirow[t]{6}{*}{ Unit cell dimensions } & $a=10.8604(3) \AA$ & $a=10.8827(3) \AA$ & $a=16.0265(5) \AA$ \\
\hline & $b=9.7288(3) \AA$ & $b=11.0853(4) \AA$ & $b=18.9031(5) \AA$ \\
\hline & $c=21.8042(6) \AA$ & $c=11.3916(2) \AA$ & $c=14.5969(4) \AA$ \\
\hline & & $\alpha=95.334(2)^{\circ}$ & \\
\hline & $\beta=92.492(2)^{\circ}$ & $\beta=100.076(2)^{\circ}$ & $\beta=107.211(3)^{\circ}$ \\
\hline & & $\gamma=99.549(2)^{\circ}$ & \\
\hline Volume & $2301.62(11) \AA^{3}$ & $1323.75(7) \AA^{3}$ & $4224.1(2) \AA^{3}$ \\
\hline$Z$ & 4 & 2 & 8 \\
\hline Absorption coefficient & $\rho(\operatorname{CuK} \alpha)=12.163 \mathrm{~mm}^{-1}$ & $\rho(\operatorname{MoK} \alpha)=5.383 \mathrm{~mm}^{-1}$ & $\rho(\mathrm{CuK} \alpha)=14.402 \mathrm{~mm}^{-1}$ \\
\hline$F(000)$ & 1176 & 652 & 2352 \\
\hline Theta range for data collection & 4.058 to $66.780^{\circ}$ & 2.960 to $26.370^{\circ}$ & 3.69 to $73.28^{\circ}$ \\
\hline Reflections collected & 20515 & 14350 & 20764 \\
\hline Independent reflections & $4034[R(\mathrm{int})=0.0291]$ & $5361[R(\mathrm{int})=0.0282]$ & $8214[R(\mathrm{int})=0.0256]$ \\
\hline Observed reflections & 3631 & 5049 & 7411 \\
\hline Completeness to theta $\max$ & $98.8 \%$ & $99.0 \%$ & $99.3 \%$ \\
\hline Absorption correction & Gaussian & Gaussian & Gaussian \\
\hline$T_{\min } / T_{\max }$ & $0.559 / 0.705$ & $0.466 / 0.718$ & $0.248 / 0.407$ \\
\hline Refinement method & Full-matrix least-squares on $F^{2}$ & Full-matrix least-squares on $F^{2}$ & Full-matrix least-squares on $F^{2}$ \\
\hline Data/restraints/parameters & $4034 / 0 / 280$ & $5357 / 0 / 325$ & $8214 / 0 / 541$ \\
\hline Goodness-of-fit on $F^{2}$ & 1.20 & 1.33 & 1.10 \\
\hline Final $R$ indices $[I>3 \sigma(I)]$ & $R_{1}=0.0165, \mathrm{w} R_{2}=0.0399$ & $R_{1}=0.0177, \mathrm{w} R_{2}=0.0449$ & $R_{1}=0.0186, \mathrm{w} R_{2}=0.0438$ \\
\hline$R$ indices (all data) & $R_{1}=0.0197, \mathrm{w} R_{2}=0.0414$ & $R_{1}=0.0208, \mathrm{w} R_{2}=0.0459$ & $R_{1}=0.0223, \mathrm{w} R_{2}=0.0460$ \\
\hline Largest diff. peak and hole & 0.63 and $-0.50{\mathrm{e} \AA^{-3}}^{-3}$ & 0.59 and $-0.60{\mathrm{e} \AA^{-3}}^{-3}$ & 0.35 and $-0.59{\mathrm{e} \AA^{-3}}^{-3}$ \\
\hline
\end{tabular}

and ensure the optimized structures of the molecules, frequency calculations were carried out using analytical second derivatives. In all cases only real frequencies were obtained for the optimized structures. The solvent effects of $\mathrm{CH}_{2} \mathrm{Cl}_{2}$ were taken into account using the PCM model. ${ }^{20,21}$ Computations of electronic absorption spectra using time-dependent DFT (TD-DFT) were carried out at the same level. The composition of the molecular orbitals and theoretical absorption spectra were plotted using the Chemissian program. ${ }^{22,23}$ The NBO analyses were carried out on the stationary points using the NBO 3.1 program $^{24}$ as implemented in the Gaussian 03 program suite.

\section{4. $\mathrm{X}$-ray structure determination}

Single crystals of $\mathbf{1 c}, \mathbf{2} \mathbf{e}$ and $\mathbf{3 b}$ were obtained by slow evaporation from a $\mathrm{CH}_{2} \mathrm{Cl}_{2}$ solution. X-ray diffraction data of suitable single-crystals of $\mathbf{1 c}, 2 \mathbf{e}$ and $3 \mathbf{b}$ were collected at $296 \mathrm{~K}(\mathbf{1 c})$ and $123 \mathrm{~K}(2 \mathbf{e}$ and $3 \mathbf{b})$ by the $\omega$-scan technique on Agilent Technologies four-circle diffractometers: $2 \mathbf{e}$ on an Xcalibur with an Eos CCD detector and monochromated $\mathrm{MoK}_{\alpha}$ radiation $(\lambda=0.71073 \AA)$, and $1 \mathbf{c}$ and $3 \mathbf{b}$ on a SuperNova with an Atlas CCD detector, equipped with a Nova microfocus $\mathrm{Cu}-\mathrm{K}_{\alpha}$ radiation source $(\lambda=1.54184 \AA)$. The obtained diffraction data were corrected for Lorentz- and polarization effects and corrected by analytical absorption corrections using the CrysAlisPro software package. ${ }^{25}$ The crystals were fixed on a microloop in mineral oil and the crystal structures of the title compounds were solved with Superflip ${ }^{26}$ in the JANA2006 program package. ${ }^{27}$ The positions of all the non-hydrogen atoms were found from structure solutions and were then subsequently refined with anisotropic displacement parameters. $\mathrm{H}$ atoms were inserted by geometrical considerations and refined by the riding model with fixed bond distances and a displacement parameter derived from that of the central atom.

It has to be noted that the crystal structure of $\mathbf{3 b}$ contains two crystallographically independent molecules which differ only slightly in their geometrical parameters. However, no hint of a superstructure was found (Table 1).

Atomic coordinates and displacement parameters are deposited with the CCDC 1513089(1c), 1513090(2e) and 1513088(3b) contain the supplementary crystallographic data for this paper. $\dagger$

\section{Results and discussion}

\subsection{Synthesis}

The synthetic routes used in the present work are depicted in Scheme 1. The known starting complexes $\left[\mathrm{Pt}\left(p-\mathrm{MeC}_{6} \mathrm{H}_{4}\right)(\mathrm{bhq})-\right.$ $\left.\left(\mathrm{SMe}_{2}\right)\right]$, in which bhq is deprotonated benzo[ $\left.h\right]$ quinoline, ${ }^{28}$ $\left[\mathrm{Pt}(\mathrm{bhq})\left(\mathrm{CF}_{3} \mathrm{CO}_{2}\right)\left(\mathrm{SMe}_{2}\right)\right]$ and $[\mathrm{Pt}(\mathrm{bhq}) \mathrm{Cl}(\mathrm{DMSO})],{ }^{15}$ have all been prepared as reported previously. Also as is described in scheme 1, the cyclometalated organoplatinum(II) complexes $\left[\operatorname{Pt}\left(p-\mathrm{MeC}_{6} \mathrm{H}_{4}\right)(\mathrm{bhq})(\mathrm{L})\right]$, in which $\mathrm{L}$ is $\mathrm{PPh}_{3}(\mathbf{1 a}), \mathrm{PPh}_{2} \mathrm{Me}(\mathbf{1 b})$, or $\mathrm{PPhMe}_{2}(\mathbf{1 c})$, and $\left[\mathrm{Pt}\left(p-\mathrm{XC}_{6} \mathrm{H}_{4}\right)(\mathrm{bhq})\left(\mathrm{PPh}_{2} \mathrm{Me}\right)\right]$, in which $\mathrm{X}$ is $\mathrm{H}(\mathbf{2 a}), \mathrm{F}(\mathbf{2 b}),{ }^{t} \mathrm{Bu}(\mathbf{2 c})$, OMe (2d), or Me $(\mathbf{2 e}=\mathbf{1 b})$, were synthesized using the known method ${ }^{29}$ by reaction of the complex $\left[\operatorname{Pt}\left(p-\mathrm{XC}_{6} \mathrm{H}_{4}\right)_{2}\left(\mathrm{SMe}_{2}\right)_{2}\right]$ with 1 equiv. of bhq in acetone, followed by the reaction of the resulting product $\left[\mathrm{Pt}\left(p-\mathrm{XC}_{6} \mathrm{H}_{4}\right)(\mathrm{bhq})\left(\mathrm{SMe}_{2}\right)\right]$ with 1 equiv. of the related phosphine $\left(\mathrm{PPh}_{3}, \mathrm{PPh}_{2} \mathrm{Me}\right.$, or $\left.\mathrm{PPhMe}_{2}\right)$. Besides, the complexes $\left[\mathrm{Pt}(\mathrm{bhq}) \mathrm{X}\left(\mathrm{PPh}_{2} \mathrm{Me}\right)\right]$, in which $\mathrm{X}$ is 
<smiles>[X]c1ccc(P(CC(C)(C)C)c2ccc([X])cc2)cc1</smiles>

$\mathbf{X}=\mathrm{H}, \mathrm{F},{ }^{\mathrm{t}} \mathrm{Bu}, \mathrm{OMe}$, or $\mathrm{Me}$<smiles>Cc1ccc(-p2c3cccc4ccc5ccc[n+]2c5c43)cc1</smiles><smiles></smiles><smiles>CC(C)C(C)C1CCCC1C</smiles><smiles></smiles>

$\underline{\mathbf{L}}$ $\begin{array}{ll}\mathrm{PPh}_{3} & \mathbf{1 a} \\ \mathrm{PPh}_{2} \mathrm{Me} & \mathbf{1 b} \\ \mathrm{PPhMe}_{2} & \mathbf{1 c}\end{array}$
$\mathrm{H} \quad \mathbf{2 a}$

${ }^{\mathrm{t}} \mathrm{Bu} \quad 2 \mathrm{c}$

$\mathrm{OMe}$ 2d

$\mathrm{Me} \quad \mathbf{2 e}(\mathbf{1 b})$<smiles></smiles><smiles></smiles><smiles></smiles><smiles>CC(=O)c1ccccc1</smiles>

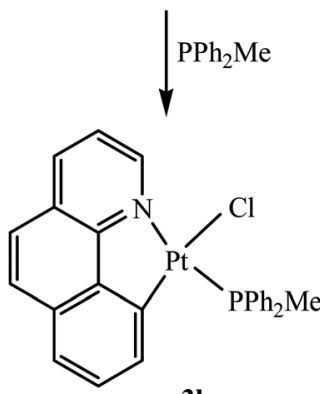

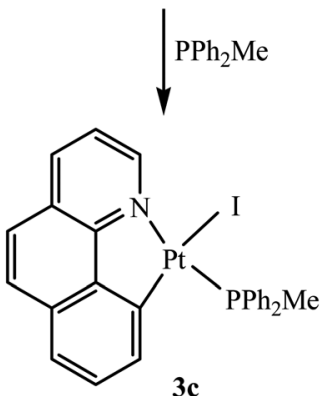

Scheme 1 Synthetic routes for the preparation of the three series of cyclometalated organoplatinum(॥) complexes.

$\mathrm{CF}_{3} \mathrm{CO}_{2}(\mathbf{3 a}), \mathrm{Cl}(\mathbf{3 b})$, or I (3c), were synthesized by the reaction of the known complexes [PtX(bhq)(S)], in which $\mathrm{S}$ is dimethyl sulfide $\left(\mathrm{SMe}_{2}\right)$ or dimethylsulphoxide (DMSO), with 1 equiv. of $\mathrm{PPh}_{2} \mathrm{Me}$ in acetone (see Scheme 1).

\subsection{Characterization}

The structures of the cyclometalated organoplatinum(II) complexes [Pt $\left.\left(p-\mathrm{MeC}_{6} \mathrm{H}_{4}\right)(\mathrm{bhq})(\mathrm{L})\right], \mathbf{1},\left[\mathrm{Pt}\left(p-\mathrm{XC}_{6} \mathrm{H}_{4}\right)(\mathrm{bhq})\left(\mathrm{PPh}_{2} \mathrm{Me}\right)\right]$, 2, and [Pt(bhq)X( $\left.\left.\mathrm{PPh}_{2} \mathrm{Me}\right)\right], 3$, in solution were characterized using ${ }^{1} \mathrm{H}$ and ${ }^{31} \mathrm{P}$ NMR spectroscopy. Typical spectra are shown in Fig. $1\left({ }^{1} \mathrm{H}\right.$ NMR spectra) and Fig. $2\left({ }^{31} \mathrm{P}\right.$ NMR spectra) for the cyclometalated organoplatinum(II) complexes $\left[\mathrm{Pt}\left(p-\mathrm{MeC}_{6} \mathrm{H}_{4}\right)\right.$ (bhq)(PPhMe $)]$, 1c, $\left[\mathrm{Pt}\left(p-\mathrm{MeC}_{6} \mathrm{H}_{4}\right)(\mathrm{bhq})\left(\mathrm{PPh}_{2} \mathrm{Me}\right)\right], \mathbf{2 e}$, and $\left[\mathrm{Pt}(\mathrm{bhq})\left(\mathrm{CF}_{3} \mathrm{CO}_{2}\right)\left(\mathrm{PPh}_{2} \mathrm{Me}\right)\right]$, 3a. In the ${ }^{1} \mathrm{H}$ NMR spectra of complexes 1c and 2e a doublet signal, accompanied by Pt satellites, was observed for the Me groups of the phosphine ligands, being trans to the $\mathrm{C}$ ligating atom of the bhq chelate, at $\delta=1.54$ (with ${ }^{2} J_{\mathrm{PH}}=8.2 \mathrm{~Hz}$ and ${ }^{3} \mathrm{~J}_{\mathrm{PtH}}=23.5 \mathrm{~Hz}$ ) and $\delta=1.49$ (with ${ }^{2} J_{\mathrm{PH}}=8.9 \mathrm{~Hz}$ and ${ }^{3} J_{\mathrm{PtH}}=27.0 \mathrm{~Hz}$ ), respectively; a similar pattern was also observed for $3 \mathrm{a}$ at $\delta=2.34$ with higher values for ${ }^{2} J_{\mathrm{PH}}(10.6 \mathrm{~Hz})$ and ${ }^{3} J_{\mathrm{PtH}}(40.4 \mathrm{~Hz})$, as compared with the corresponding values for $\mathbf{1 c}$ and $2 \mathrm{e}$. This confirms that in 3a, the phosphine ligand is situated trans to the $\mathrm{N}$ ligating atom of the bhq chelate as compared with $\mathbf{1 c}$ and $2 \mathbf{e}$ in which the phosphine ligands are located trans to the $\mathrm{C}$ ligating atom of the bhq chelate, that having a much higher trans influence than the $\mathrm{N}$ atom. Consistently, in the ${ }^{31} \mathrm{P}$ NMR spectra of each of the complexes 1c or 2e (see Fig. 2), a singlet signal accompanied by 


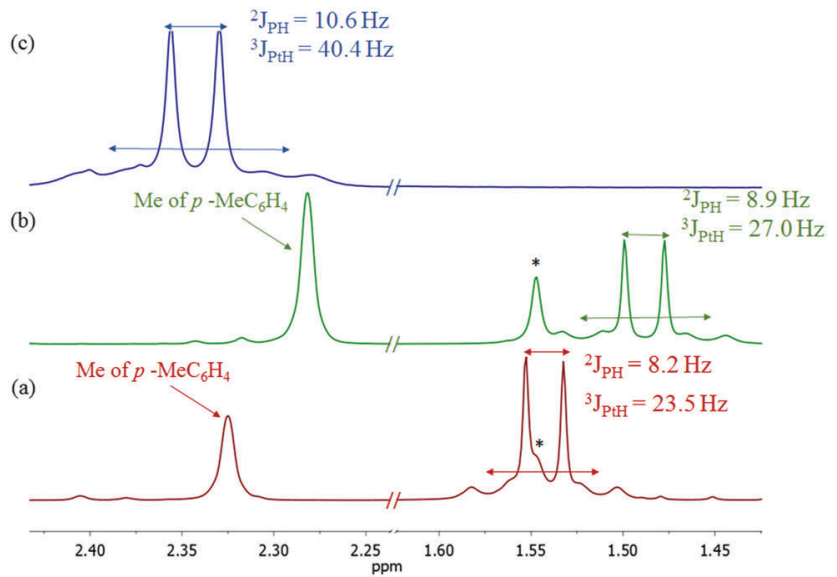

Fig. $1{ }^{1} \mathrm{H}$ NMR spectra in the Me regions of $\left[\mathrm{Pt}\left(p-\mathrm{MeC}_{6} \mathrm{H}_{4}\right)(\mathrm{bhq})(\mathrm{PPhMe})\right]$, 1c (a), [Pt $\left.\left(p-\mathrm{MeC}_{6} \mathrm{H}_{4}\right)(\mathrm{bhq})\left(\mathrm{PPh}_{2} \mathrm{Me}\right)\right], \mathbf{2 e}(\mathrm{b})$, and [Pt(bhq) $\left.\left(\mathrm{CF}_{3} \mathrm{CO}_{2}\right)\left(\mathrm{PPh}_{2} \mathrm{Me}\right)\right]$, 3a (c). Trace water impurities of NMR solvent are shown by *.

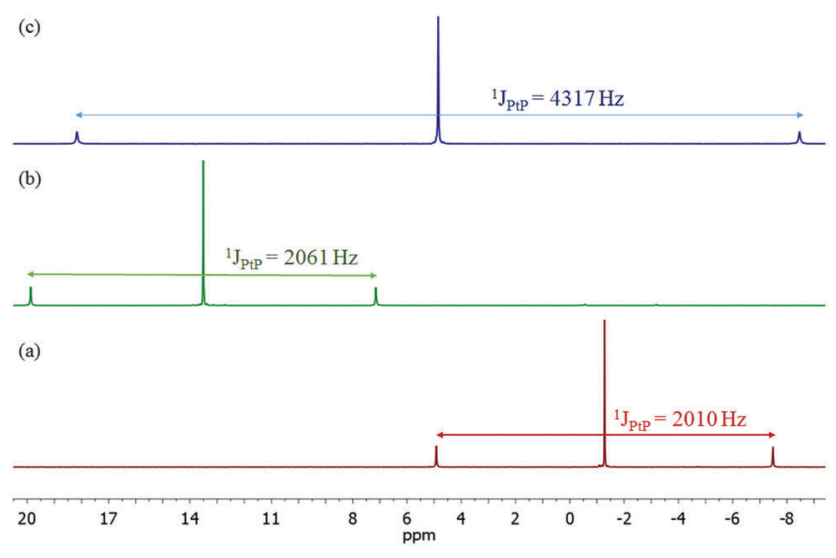

Fig. $2{ }^{31} \mathrm{P} \quad \mathrm{NMR}$ spectra of $\left[\mathrm{Pt}\left(\mathrm{p}-\mathrm{MeC}_{6} \mathrm{H}_{4}\right)(\mathrm{bhq})\left(\mathrm{PPhMe}_{2}\right)\right]$, 1c (a), $\left[\mathrm{Pt}\left(p-\mathrm{MeC}_{6} \mathrm{H}_{4}\right)(\mathrm{bhq})\left(\mathrm{PPh}_{2} \mathrm{Me}\right)\right], \mathbf{2 e}(\mathrm{b})$, and [Pt(bhq) $\left.\left(\mathrm{CF}_{3} \mathrm{CO}_{2}\right)\left(\mathrm{PPh}_{2} \mathrm{Me}\right)\right], 3 a(c)$.

Pt satellites is observed for the phosphine ligand (being trans to C) at $\delta=-1.3$ (with ${ }^{1} J_{\mathrm{PtP}}=2010 \mathrm{~Hz}$ ) or $\delta=13.5$ (with ${ }^{1} J_{\mathrm{PtP}}=2061 \mathrm{~Hz}$ ), respectively. However the corresponding signal for $3 \mathbf{a}$, with the phosphine being trans to the $\mathrm{N}$ ligating atom, was observed at $\delta=4.9$ with a much higher ${ }^{1} J_{\mathrm{PtP}}$ value of $4317 \mathrm{~Hz}$.

The structures of typical cyclometalated organoplatinum(II) complexes $\mathbf{1 c}, \mathbf{2} \mathbf{e}$ and $\mathbf{3 b}$ were further confirmed by X-ray crystallography determination. The ellipsoid representation of complexes and the packing of molecules through different kinds of intermolecular interactions are also illustrated in Fig. 3 (1c and 2e) and Fig. 4 (3b) and selected geometric parameters are listed. Suitable crystals were grown through slow diffusion of n-hexane into the $\mathrm{CH}_{2} \mathrm{Cl}_{2}$ solution of each complex. All complexes exhibit a distorted square planar geometry around the Pt center in which the chelating $\mathrm{C}^{\wedge} \mathrm{N}$ bite angles (N1-Pt1-C1) are $80.42,80.13$ and 81.02 for complexes $1 \mathbf{c}, 2 \mathbf{e}$ and $3 \mathbf{b}$, respectively. They are significantly smaller than $90^{\circ}$ which implies that the chelates are probably under strain. In complex 1c, the $p-\mathrm{MeC}_{6} \mathrm{H}_{4}$ ligand lies orthogonal at $90.2(2)^{\circ}$ to the plane of the platinum center.

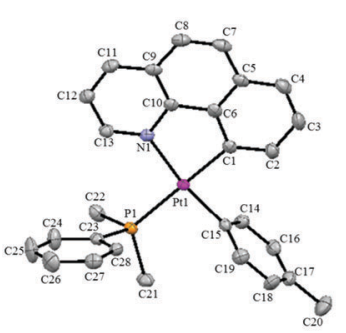

(i)

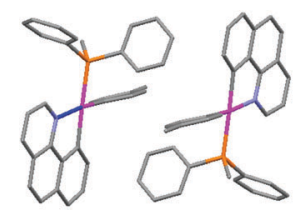

(ii)

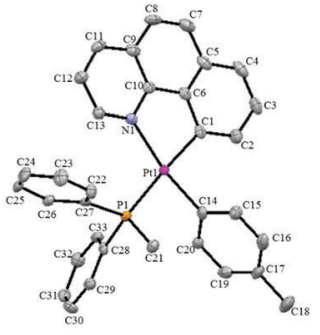

(iii)

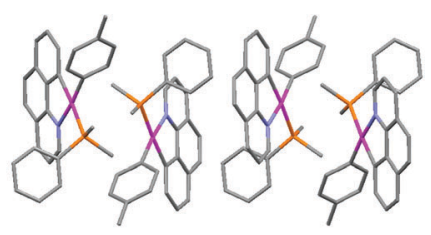

(iv)
Fig. 3 (i) Anisotropic representation and (ii) packing of molecules for the complex $\left[\left(p-\mathrm{MeC}_{6} \mathrm{H}_{4}\right)(\mathrm{bhq}) \mathrm{Pt}(\mathrm{PPhMe})\right]$, 1c. Ellipsoids are shown at the $50 \%$ probability level. Selected geometrical parameters ( $\AA$, $)^{\circ}$ : Pt1-C15 2.013(0); Pt1-C1 2.041(1); Pt1-N1 2.145(0); Pt1-P1 2.294(1); C15-Pt1-C1 90.54(0); C15-Pt1-N1 170.91(1); C1-Pt1-N1 80.42(0); C15-Pt1-P1 90.45(0); C1-Pt1-P1 176.38(0); N1-Pt1-P1 98.63(0). (iii) Anisotropic representation and (iv) packing of molecules through $\mathrm{C}-\mathrm{H} \ldots \mathrm{Pt}$ intermolecular hydrogen bonding for the complex $\left[\left(p-\mathrm{MeC}_{6} \mathrm{H}_{4}\right)(\mathrm{bhq}) \mathrm{Pt}\left(\mathrm{PPh}_{2} \mathrm{Me}\right)\right], 2 \mathrm{2e}$. Ellipsoids are shown at the $50 \%$ probability level. Selected geometrical parameters $\left(\AA \AA,{ }^{\circ}\right)$ : Pt1-C1 2.051(2); Pt1-N1 2.136(2); Pt1-C14 2.016(2); Pt1-P1 2.302(2); C1-Pt1-C14 91.34(0); C1-Pt1-N1 80.16(0); C14-Pt1-P1 85.51(0); N1-Pt1-P1 102.97(0); C1-Pt1-P1 176.84(0); N1-Pt1-C14 170.65(0). Intramolecular and intermolecular hydrogen bonds $\left(\AA,{ }^{\circ}\right)$ : $\mathrm{D}-\mathrm{H} \ldots \mathrm{A}$, for $\mathrm{C} 23-\mathrm{H} 23 \ldots \mathrm{Pt1}, d(\mathrm{D}-\mathrm{H})=0.94, d(\mathrm{H} \cdots \mathrm{A})=2.68, d(\mathrm{D} \cdots \mathrm{A})=3.59$, $\angle(D H A)=161.9$

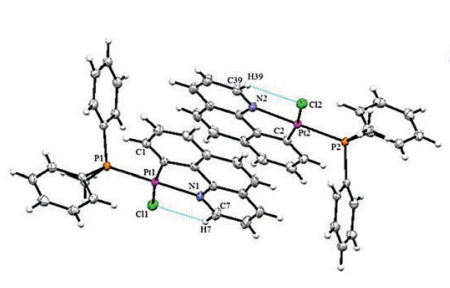

(i)

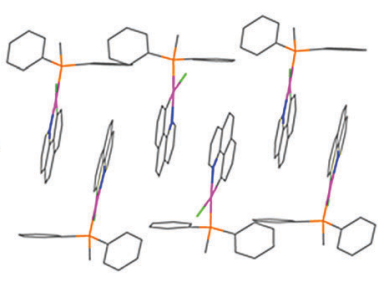

(ii)
Fig. 4 (i) ORTEP anisotropic drawing of two independent molecules and (ii) packing of molecules of the complex $\mathbf{3 b}$. Ellipsoids are shown at the $50 \%$ probability level. Selected bond lengths ( $\AA$ ) and angles ( $\left.{ }^{\circ}\right)$ : Pt1-P1 2.2243(7), Pt1-Cl1 2.3973(7), Pt1-N1 2.099(2), Pt1-C1 2.013(3), Pt2-P2 2.2242(7), Pt2-Cl2 2.3937(6), Pt2-N2 2.106(2), Pt2-C2 2.014(3); N1-Pt1-C1 81.02(10), N1-Pt1-Cl1 90.82(7), N1-Pt1-P1 176.19(7), C1-Pt1-P1 95.86(8), C1-Pt1-Cl1 170.87(8), P1-Pt1-Cl1 92.44(2), N2-Pt2-C2 81.23(11), N2-Pt2-Cl2 90.60(7), N2-Pt2-P2 176.74(7), C2-Pt2-Cl2 171.30(8), C2-Pt2-P2 96.06(8), Cl2-Pt2-P2 92.20(2). Intramolecular hydrogen bonds $\left(\AA \AA{ }^{\circ}\right)$ : $\mathrm{D}-\mathrm{H} \cdots \mathrm{A}$, for $\mathrm{C} 7-\mathrm{H} 7 \ldots \mathrm{Cl}, d(\mathrm{D}-\mathrm{H})=0.93, d(\mathrm{H} \cdots \mathrm{A})=2.57$, $d(D \cdots A)=3.24, \angle(D H A)=129.0$; for $C 39-H 39 \cdots C l 2, d(D-H)=0.92$, $d(\mathrm{H} \cdots \mathrm{A})=2.62, d(\mathrm{D} \cdots \mathrm{A})=3.25, \angle(\mathrm{DHA})=125.8$

Complex $\mathbf{3 b}$ was crystallized in the monoclinic crystal system in the space group of $P 2_{1} / c$. Two crystallographically different but chemically identical complexes are located in the asymmetric unit. Bond lengths and angles are slightly different for the independent molecules. No hints of higher symmetry 
Table 2 Electronic absorption data for the studied complexes in $\mathrm{CH}_{2} \mathrm{Cl}_{2}$ solution (ca. $3 \times 10^{-5} \mathrm{M}$ ) at $298 \mathrm{~K}$

\begin{tabular}{ll}
\hline & $\lambda_{\max }, \mathrm{nm}\left(\varepsilon \times 10^{-3} \mathrm{M}^{-1} \mathrm{~cm}^{-1}\right)$ \\
\hline 1a & $290(18.2), 324(11.2), 379(4.2), 403(2.5)$ \\
1b $(2 \mathbf{e})$ & $261(32.7), 290(16.4), 309(14.3), 325(10.7), 378(4.3), 404(2.4)$ \\
1c & $260(33.97), 290(16.8), 324(10.7), 376(4.3), 405(2.4)$ \\
2a & $259(33.0), 285(22.2), 325(7.1), 373(2.8), 408(1.3)$ \\
2b & $260(31.7), 305(13.9), 328(8.3), 414(2.99)$ \\
2c & $260(36.5), 290(24.3), 326(7.5), 376(3.2), 413(1.4)$ \\
2d & $258(37.4), 292(22.4), 327(7.6), 375(3.4), 410(2.0)$ \\
3a & $253(40.0), 287(19.0), 304(16.8), 325(7.9), 390(3.0), 408(3.2)$ \\
3b & $258(35.0), 305(14.7), 394(3.1), 413(3.4)$ \\
3c & $264(34.6), 310(12.5), 344(3.6), 417(2.0)$
\end{tabular}

were found. As expected, the bhq ligand in complex $\mathbf{3 b}$ binds to the $\mathrm{Pt}^{\mathrm{II}}$ metal center via two $\mathrm{N}$ and $\mathrm{C}$ atoms. The angles around the Pt center deviate significantly from $90^{\circ}$, i.e. the (bhq) bite angles, C1-Pt1-N1 and $\mathrm{C} 2-\mathrm{Pt} 2-\mathrm{N} 2$ are reduced to $81.02(10)^{\circ}$ and $81.23(11)^{\circ}$, respectively, implying that the chelate is probably under strain, whereas the angles formed by the chlorine ligand trans to $\mathrm{C}$ with the $\mathrm{P}$ atom of $\mathrm{PPh}_{2} \mathrm{Me}$, i.e. $\mathrm{P} 1-\mathrm{Pt} 1-\mathrm{Cl} 1$ and $\mathrm{P} 2-\mathrm{Pt} 2-\mathrm{Cl} 2$, are increased to $92.44(2)^{\circ}$ and $92.20(2)^{\circ}$, respectively. The shortest intermolecular $\pi$-stacking distance of the bhq groups for complex $3 \mathbf{b}$ is $\approx 3.6 \AA$ (Fig. 4). Molecules of this complex assemble to give a supramolecular polymer structure through $\pi$-stacking between parallel bhq groups, as shown in Fig. 4ii, while in the adjacent molecules of complexes $1 \mathrm{c}$ and $2 \mathrm{e}$ secondary bonding occurs through a series of edge-to-face and vertex-to-face aryl $\cdots$ aryl attractions (Fig. 3ii and iv).

\subsection{Electronic absorption spectra}

The UV-vis absorption spectra of the studied cyclometalated organoplatinum(II) complexes were obtained in $\mathrm{CH}_{2} \mathrm{Cl}_{2}$ solutions at $298 \mathrm{~K}$; the consequent data are summarized in Table 2 and the spectra are shown in Fig. 5. All complexes exhibit intense $\left(\varepsilon>10^{4} \mathrm{M}^{-1} \mathrm{~cm}^{-1}\right.$ ) high-energy bands ( $\lambda$ range: $250-350 \mathrm{~nm}$ ) as well as significantly less intense $\left(\varepsilon: 4-4.3 \times 10^{3} \mathrm{M}^{-1} \mathrm{~cm}^{-1}\right)$ low-energy absorptions ( $\lambda$ range: $350-450 \mathrm{~nm}$ ). These transitions are comparable to those reported for the complex $\left[\mathrm{Pt}\left(p-\mathrm{MeC}_{6} \mathrm{H}_{4}\right)(\mathrm{bhq})\left(\mathrm{SMe}_{2}\right)\right]$, showing that ${ }^{1} \mathrm{LC}$ transitions within the bhq ligand $\left(\pi-\pi^{*}\right)$ are dominating. ${ }^{6}$
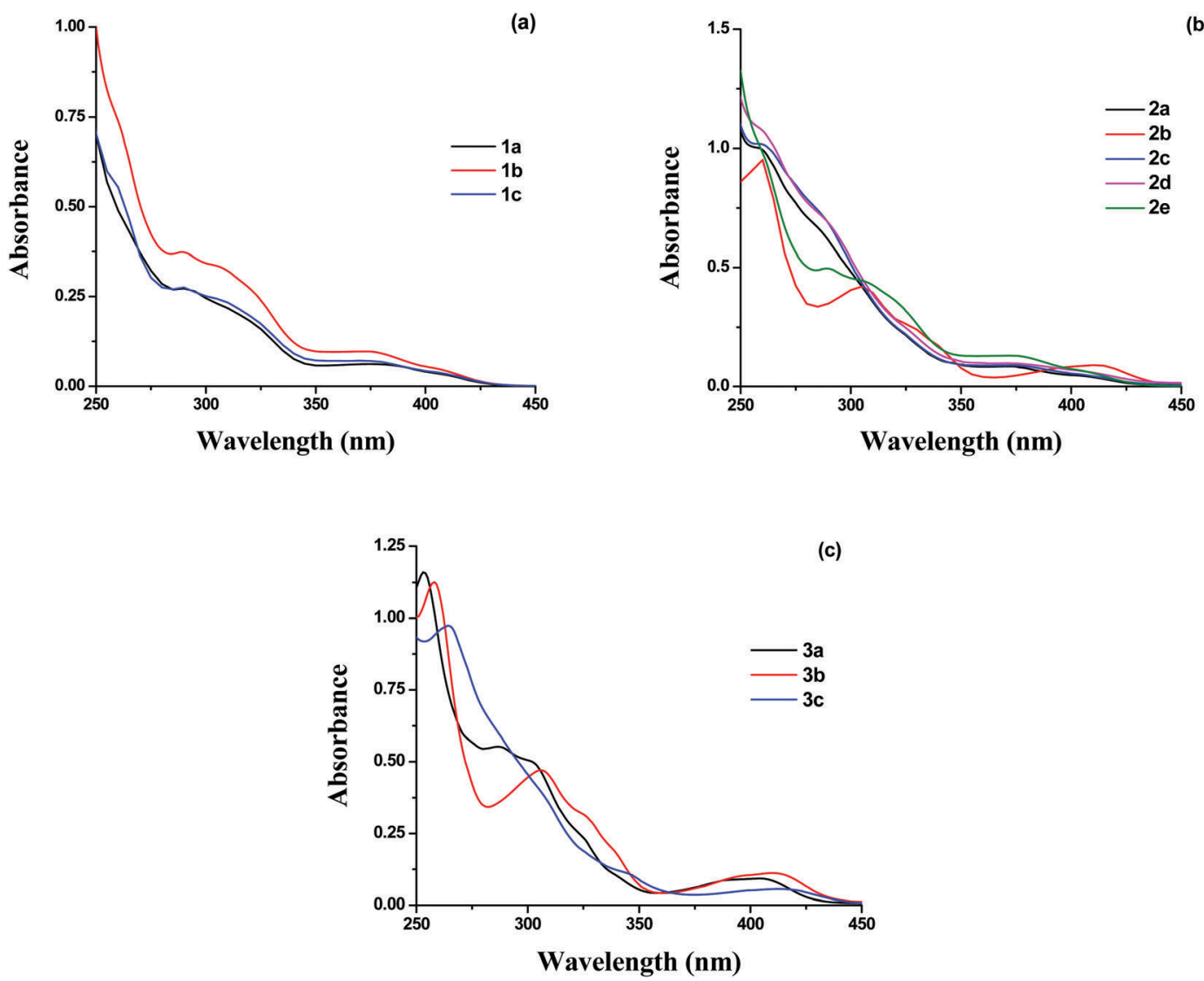

Fig. 5 UV-visible absorption spectra, in $\mathrm{CH}_{2} \mathrm{Cl}_{2}$ at $298 \mathrm{~K}: \mathbf{1}$ (a), 2 (b), and $\mathbf{3}$ (c). 
Table 3 Emission data of the studied complexes

\begin{tabular}{|c|c|c|c|c|c|}
\hline Complex & $\lambda(\mathrm{nm})$ & $\phi^{a}$ & $\tau(\mu \mathrm{s})$ & $k_{\mathrm{r}}^{b}\left(\mathrm{~s}^{-1}\right)$ & $k_{\mathrm{nr}}^{b}\left(\mathrm{~s}^{-1}\right)$ \\
\hline 1a & $489_{\max }, 524,567_{\mathrm{sh}}$ & 5 & 57.34 & $9.0 \times 10^{2}$ & $1.7 \times 10^{4}$ \\
\hline $\mathbf{1 b}(=2 \mathbf{e})$ & $\begin{array}{l}483_{\max }, 516,562_{\mathrm{sh}} \\
350,366,385_{\mathrm{sh}} \mathrm{c}\end{array}$ & 3 & 12.37 & $2.4 \times 10^{3}$ & $7.8 \times 10^{4}$ \\
\hline 1c & $\begin{array}{l}485_{\max }, 513,560_{\mathrm{sh}} \\
350,365,384_{\mathrm{sh}}{ }^{c}\end{array}$ & 11 & 58 & $1.9 \times 10^{3}$ & $1.5 \times 10^{4}$ \\
\hline $2 \mathbf{a}$ & $488_{\max }, 523,571_{\mathrm{sh}}$ & 14.6 & 74 & $2.0 \times 10^{3}$ & $1.2 \times 10^{4}$ \\
\hline $2 b$ & $476_{\max }, 506,545_{\mathrm{sh}}$ & 2.1 & 10.6 & $2.0 \times 10^{3}$ & $9.2 \times 10^{4}$ \\
\hline $2 \mathrm{c}$ & $474_{\max }, 505,548_{\mathrm{sh}}$ & 2.6 & 17.52 & $1.5 \times 10^{3}$ & $5.6 \times 10^{4}$ \\
\hline $2 d$ & $493_{\max }, 526,578_{\mathrm{sh}}$ & 0.8 & 14 & $6.0 \times 10^{2}$ & $7.1 \times 10^{4}$ \\
\hline $3 \mathbf{a}$ & $495_{\max }, 527,577_{\mathrm{sh}}$ & 1.3 & 12.18 & $1.1 \times 10^{3}$ & $8.1 \times 10^{4}$ \\
\hline $3 \mathbf{b}$ & $501,532,570_{\max }$ & 1.8 & 20 & $9.0 \times 10^{2}$ & $4.9 \times 10^{4}$ \\
\hline $3 \mathbf{c}$ & $484,541_{\max }, 592$ & 1.2 & 15 & $8.0 \times 10^{2}$ & $6.6 \times 10^{4}$ \\
\hline
\end{tabular}

${ }^{a}$ In percent. ${ }^{b}$ Radiative rate constant $k_{\mathrm{r}}=\phi / \tau$, non-radiative rate constant $k_{\mathrm{nr}}=(1-\phi) / \tau$. ${ }^{c}$ Measured in dichloromethane.

The lowest-energy band in either of the cyclometalated organoplatinum(II) complexes 1a-1c comprises [LLCT; $\pi(p$-tol $) \rightarrow$ $\left.\pi^{*}(\mathrm{bhq})\right],\left[\mathrm{MLCT} ; \mathrm{d} \sigma(\mathrm{Pt}) \rightarrow \pi^{*}(\mathrm{bhq})\right]$ and [LC; $\left.\pi \rightarrow \pi^{*}(\mathrm{bhq})\right]$ transitions, showing slight dependence on the nature of the phosphine ligands. The lowest-energy slopes in the spectra of the series of complexes $\left[\mathrm{Pt}\left(p-\mathrm{XC}_{6} \mathrm{H}_{4}\right)(\mathrm{bhq})\left(\mathrm{PPh}_{2} \mathrm{Me}\right)\right], 2$, appear at around $408 \mathrm{~nm}$; they all have [MLCT; $\left.\mathrm{d} \sigma(\mathrm{Pt}) \rightarrow \pi^{*}(\mathrm{bhq})\right]$ and [LC; $\left.\pi \rightarrow \pi^{*}(\mathrm{bhq})\right]$ transitions, with complexes $2 \mathrm{c}$ and $2 \mathrm{e}$ (X being an electron donor alkyl group ${ }^{t} \mathrm{Bu}$ and $\mathrm{Me}$, respectively) having additional [LLCT; $\pi\left(p-\mathrm{XC}_{6} \mathrm{H}_{4}\right) \rightarrow \pi^{*}(\mathrm{bhq})$ ] transitions. The absorption spectra of the complexes [Pt(bhq)X( $\left.\left.\mathrm{PPh}_{2} \mathrm{Me}\right)\right], 3$, are in general similar to those found for the other series (1 or 2) although their maxima show minor changes with the variation of anionic ligands indicating that they arise mostly from ${ }^{1} \mathrm{LC}(\mathrm{bhq})$ transitions. The slope of the lowest-energy maxima slightly shifts to lower energies according to the $\pi$-donating ability of the $\mathrm{X}$ ligands by the sequence $\mathrm{CF}_{3} \mathrm{CO}_{2}{ }^{-}(408 \mathrm{~nm})<\mathrm{Cl}^{-}(413 \mathrm{~nm})<\mathrm{I}^{-}$ $(417 \mathrm{~nm})$. It shows that the iodide ligand possesses a significant $\pi$-donating ability due to the presence of available (high-lying) lone pairs, and these bands originate from ligand-to-ligand charge-transfer [LLCT; $\left.\mathrm{I}^{-} \rightarrow \pi^{*}(\mathrm{bhq})\right]$, [MLCT; d $\left.\sigma(\mathrm{Pt}) \rightarrow \pi^{*}(\mathrm{bhq})\right]$ and $\left[\mathrm{LC} ; \pi \rightarrow \pi^{*}(\mathrm{bhq})\right]$.

\subsection{Luminescence properties}

Detailed experimental data of the emission properties of complexes 1-3 in the solid state are collected in Table 3 and theoretical investigations were performed to explain the corresponding behaviours of the studied complexes (see below). These complexes in the solid state (powder form) at $298 \mathrm{~K}$ are emissive upon photoexcitation (see Fig. 6). All complexes with bhq cyclometalated ligands are shown to exhibit a structured profile emission band involving a main peak, a vibronic progression, and a shoulder and these characteristics indicate that in all cases, the emissions arise from a triplet excited state essentially centered on (a)

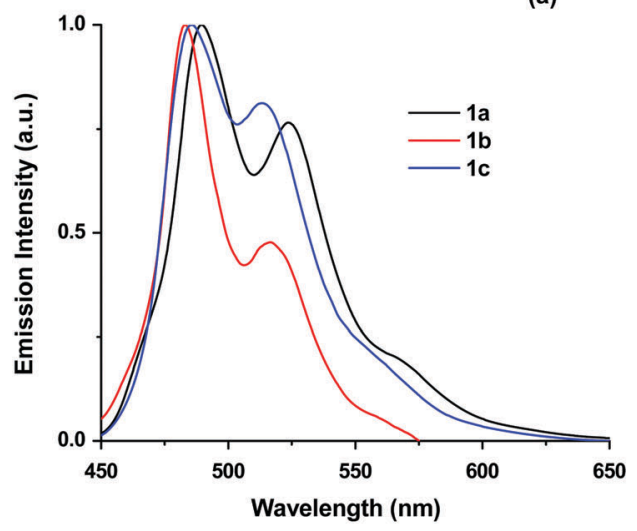

(b)

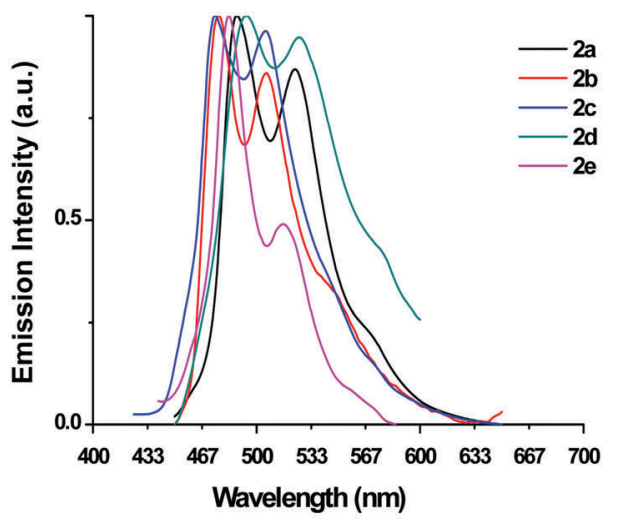

(c)

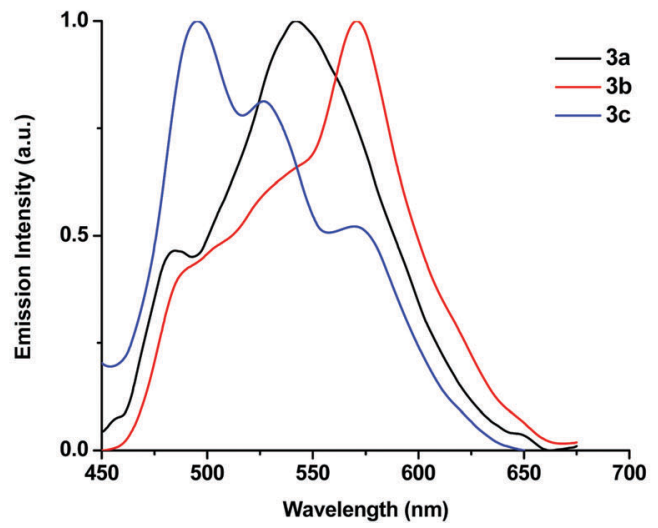

Fig. 6 Luminescence spectra of 1 (a), 2 (b) and $\mathbf{3}$ (c) in the solid state at $298 \mathrm{~K}$. 
Table 4 TD-DFT calculated transitions of the lowest-lying wavelengths and main components of the singlet and triplet excited states of typical complexes $\mathbf{1 c}, \mathbf{2} \mathbf{b}$ and $\mathbf{3 b}$

\begin{tabular}{|c|c|c|c|c|}
\hline Complex & State & Configuration (percentage contribution) & $\lambda_{\text {calc. }[\exp ] / \mathrm{nm}}$ & Main character \\
\hline & Triplet & LSOMO $\rightarrow$ HSOMO $(66)$ & $644[560]$ & MLCT/LC \\
\hline $2 \mathbf{b}$ & Triplet & $\begin{array}{l}\text { LSOMO } \rightarrow \text { HSOMO }(71) \\
\text { LSOMO }-3 \rightarrow \text { HSOMO }(12)\end{array}$ & $640[545]$ & $\mathrm{MLCT} / \mathrm{LC}$ \\
\hline & Singlet & HOMO $\rightarrow$ LUMO $(96)$ & $394[413]$ & MLCT/LC/LLCT \\
\hline
\end{tabular}

the bhq ligands $\left({ }^{3} \mathrm{LC}\right)$ involving a mild degree of MLCT admixture. ${ }^{30}$ As such, comparable patterns were observed in the emission spectra of all our cyclometalated organoplatinum(II) complexes (Fig. 6) giving rise to almost similar emissions and lifetimes in the microsecond range. Although varying the ancillary ligands in the studied cyclometalated organoplatinum(II) complexes (i.e. phosphines, anionic, and aryls) shows an effect on the shape and energy of the emission bands, they have an influence on the emission intensities at room temperature. Solid state absolute quatum yields of the complexes $\left[\mathrm{Pt}(\mathrm{Ph})(\mathrm{bhq})\left(\mathrm{PPh}_{2} \mathrm{Me}\right)\right], \mathbf{2 a}$, and $\left[\mathrm{Pt}\left(p-\mathrm{MeC}_{6} \mathrm{H}_{4}\right)(\mathrm{bhq})(\mathrm{PPhMe})\right], 1 \mathrm{c}$, being respectively 0.146 and 0.110, are much higher than those observed for the other cyclometalated organoplatinum(II) complexes (the quantum yields for complexes 1a, 2b, 2c, 2d, 2e, 3a, 3b, and $3 \mathbf{c}$ are measured to be $0.05,0.021,0.026,0.008,0.030,0.013,0.018$, and 0.012 , respectively).

In the normalized emission spectra of the cyclometalated organoplatinum(II) complexes $\mathbf{1}$ in the solid state at room temperature (see Fig. $6 \mathrm{a}$ ), the $\lambda_{\mathrm{em}}$ for the main peaks, vibronic progression peaks, and shoulders appear at about $485 \mathrm{~nm}$, $520 \mathrm{~nm}$, and $560 \mathrm{~nm}$, respectively. The lowest-energy maxima are marginally shifted to lower energies as 1c (having $\mathrm{PPhMe}_{2}$ ligand) < 1b (having $\mathrm{PPh}_{2} \mathrm{Me}$ ligand) $<1$ a (having $\mathrm{PPh}_{3}$ ligand). As we progress from $1 \mathrm{c}$ to $1 \mathrm{a}$, the number of $\mathrm{Ph}$ groups on the related phosphine ligand increases and this is expected to decrease the MLCT contribution. This is compensated by the reverse behavior of the LLCT and the above trend is finally obtained.

As can be observed in Fig. 6b, the cyclometalated organoplatinum(II) complexes $\left[\mathrm{Pt}\left(p-\mathrm{XC}_{6} \mathrm{H}_{4}\right)(\mathrm{bhq})\left(\mathrm{PPh}_{2} \mathrm{Me}\right)\right], 2$, are luminescent in the solid state with $\lambda_{\mathrm{em}}$ between 474 and $494 \mathrm{~nm}$ with a tail to lower energies, giving rise to emission bands that are very similar in shape and energy to those found for the $\mathbf{1}$ isomers. The lowest-energy maxima are dependent on $\mathrm{X}$ and are located at $545 \mathrm{~nm}$ (for $2 \mathrm{~b}$ with $\mathrm{X}=\mathrm{F}$ ) and $577 \mathrm{~nm}$ (for $2 \mathrm{~d}$ with $\mathrm{X}=\mathrm{OMe}$ ) and the results are consistent with $\mathrm{OMe}$ being an electron donor to the Ar ligand (as compared with $\mathrm{F}$ having electron withdrawing ability) making the metallic center richer and thus increasing the MLCT contribution; as such the contribution from LLCT is also increased. The lowest-energy maxima for the other complexes with $\mathrm{X}$ being $\mathrm{H}(\mathbf{2 a}),{ }^{t} \mathrm{Bu}(\mathbf{2 c})$, and $\mathrm{Me}(\mathbf{2 e})$ are situated in between the $\mathbf{2 b}$ and $\mathbf{2 d}$ extremes.

Solid state emission spectra of the cyclometalated organoplatinum(II) complexes [Pt(bhq)X( $\left.\left.\mathrm{PPh}_{2} \mathrm{Me}\right)\right], 3$, at $298 \mathrm{~K}$ have also been recorded (see Fig. 6c) showing that each emission is dependent on the contributions from different transitions (see Tables S32, S36, and S40, ESI $\dagger$ ). Notice that the transition admixtures for the tails of the lowest-energy maxima for complexes $3 \mathbf{b}(\mathrm{X}=\mathrm{Cl})$ and $3 \mathbf{c}(\mathrm{X}=\mathrm{I})$ are MLCT/LC/LLCT, while for complex 3a $\left(\mathrm{X}=\mathrm{CF}_{3} \mathrm{CO}_{2}\right)$, probably with the electron withdrawing $\mathrm{CF}_{3}$ group preventing donation of the lone pair of the $\mathrm{O}$ atom connected to the metal center, the related transition admixture is MLCT/LC with no contribution from LLCT, showing a rather significant blue shift as compared with $\mathbf{3 a}$ and $\mathbf{3 b}$ ).

The lifetime values for all the cyclometalated organoplatinum(II) complexes studied in the present work (see Table 3) are in the microsecond domain, showing a triplet excited state with phosphorescence character.

\subsection{Computational study}

Density functional theory (DFT) and time-dependent TD-DFT calculations were performed for all the cyclometalated organoplatinum(II) complexes. The structures were fully optimized and the resulting structures are presented in the Supporting Information. As can be observed in Tables S41-S43 (ESI $\dagger$ ), the calculated bond distances and angles are in good agreement with the values obtained from the X-ray crystal structure determination. The negligible differences between the experimental and calculated bond lengths and angles are due to the fact that the computations were performed in the gas phase, while the X-ray data were obtained in the solid phase. To investigate the absorption properties of the cyclometalated organoplatinum(II) complexes, TD-DFT calculations were performed at the B3LYP level of density functional theory. Excitation energies at the groundstate geometries were calculated by TD-DFT in $\mathrm{CH}_{2} \mathrm{Cl}_{2}$ solution and the gas phase. The data for selected singlet and triplet excitations are given in the Supporting Information and for typical complexes $\mathbf{1 c}, \mathbf{2 b}$ and $\mathbf{3 b}$ are given in Tables 4 and 5 . The predicted singlet excitation energies and oscillator strengths are in compliance with the experimental absorption spectra in all the cases. The lowest-energy singlet transition with a significant oscillator strength in all of the cyclometalated organoplatinum(II) complexes is a primarily ligand-centered, LC, (bhq) transition with small contribution of MLCT character, which matches with the experimental absorption between 403 and $417 \mathrm{~nm}$. The lowest singlet excited states in the cyclometalated organoplatinum(II) complex series of $\left[\mathrm{Pt}\left(p-\mathrm{MeC}_{6} \mathrm{H}_{4}\right)(\mathrm{bhq})(\mathrm{L})\right]$, 1, are derived from the HOMO $\rightarrow$ LUMO and HOMO-1 $\rightarrow$ LUMO 


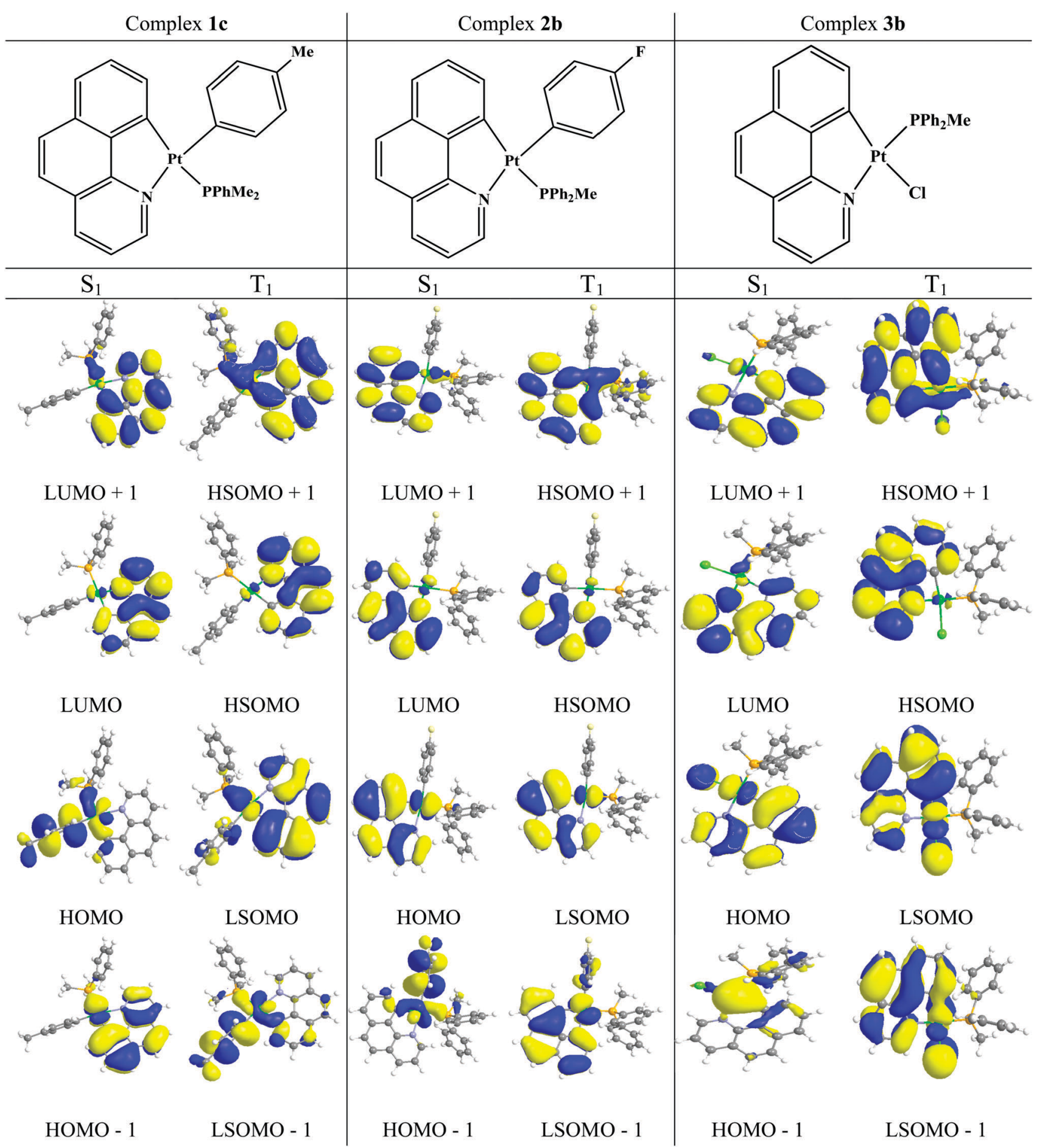

transitions. The $S_{0} \rightarrow S_{1}$ transition originates from the mixed LC/MLCT/LLCT ( $\mathrm{L}=$ bhq and $p$-tolyl, $\mathrm{M}=\mathrm{Pt}$ ) transitions. The calculated charge on the $\mathrm{Pt}$ atom is negative for $\left[\mathrm{Pt}\left(p-\mathrm{MeC}_{6} \mathrm{H}_{4}\right)(\mathrm{bhq})\left(\mathrm{PPh}_{3}\right)\right], \mathbf{1 a},(-0.001)$ in comparison with the positive charge in the other two $(0.007$ and 0.026 for $\mathbf{1 b}$ and $\mathbf{1 c}$ derivatives respectively) that can be attributed to the number of phenyl groups in the phosphine ligands. The lowest-energy transition in the cyclometalated organoplatinum(II) complex series of $\left[\mathrm{Pt}\left(p-\mathrm{XC}_{6} \mathrm{H}_{4}\right)(\mathrm{bhq})\left(\mathrm{PPh}_{2} \mathrm{Me}\right)\right], 2$, corresponds to the mixed LC/MLCT $\left[\pi(\mathrm{bhq}) / \mathrm{d} \sigma(\mathrm{Pt}) \rightarrow \pi{ }^{*}(\mathrm{bhq})\right]$. In the case of 2d, the lowest energy transition is calculated to be the mixed LLCT/MLCT $\left[\left(p-\mathrm{MeOC}_{6} \mathrm{H}_{4}\right) / \mathrm{d} \sigma(\mathrm{Pt}) \rightarrow \pi^{*}(\mathrm{bhq})\right]$ transitions. In comparison with $2 \mathrm{a}$ with the cyclometalated phenyl group, complex 2b bearing the 4-fluorophenyl group reveals an $\sim 12 \mathrm{~nm}$ 
hypsochromic shift in the emission peak wavelength and can qualitatively be rationalized by a decrease in $\pi$ MO energy level due to the stronger electron-withdrawing character of the fluorine atom at a para position. For the cyclometalated organoplatinum(II) complex series of [Pt(bhq) $\left.\mathrm{X}\left(\mathrm{PPh}_{2} \mathrm{Me}\right)\right], 3$, the lowest-energy transition is related to the mixed LC/MLCT $\left[\pi(\mathrm{bhq}) / \mathrm{d} \sigma(\mathrm{Pt}) \rightarrow \pi^{*}(\mathrm{bhq})\right]$ transitions with an additional LLCT character in $3 \mathrm{c}(\mathrm{X}=\mathrm{I})[\mathrm{p}(\mathrm{I}) \rightarrow$ $\left.\pi^{*}(\mathrm{bhq})\right]$ which is responsible for the long tail observed in the experimental absorption spectrum of 3c; more intense bands at higher energies in 3 complexes seem to be related to the mixed LC/LLCT/MLCT $\left[\pi(\mathrm{bhq}) / \mathrm{p}(\mathrm{X}) / \mathrm{d}(\mathrm{Pt}) \rightarrow \pi^{*}(\mathrm{bhq})\right]$ transitions. Although in $\mathbf{3 a}$ and $\mathbf{3 b}$, there are negligible contributions from $\mathrm{p}\left(\mathrm{CF}_{3} \mathrm{CO}_{2}\right)$ and $\mathrm{p}(\mathrm{Cl})$ orbitals, the contributions from $\mathrm{p}(\mathrm{I})$ orbitals in $3 c$ are appreciably higher and almost $50 \%$ of the HOMO-1 is iodine p-orbitals.

The TD-DFT results show ${ }^{3} \mathrm{LC}(\mathrm{bhq})$ character as the lowest triplet $\left(\mathrm{T}_{1}\right)$ in the calculated cyclometalated organoplatinum(II) complexes, with different contributions of MLCT or LLCT character, agreeing with the obtained experimental emissions. It is noteworthy that a relatively high amount of MLCT character is found in the first three triplets of all of the complexes. The lowest-energy triplet in the cyclometalated organoplatinum(II) complex series of $\left[\mathrm{Pt}\left(p-\mathrm{MeC}_{6} \mathrm{H}_{4}\right)(\mathrm{bhq})(\mathrm{L})\right], \mathbf{1}$, the $\mathbf{1 a}$ and $\mathbf{1 b}$ complexes have a mixed LLCT/MLCT/LC character $[\mathrm{d} \sigma(\mathrm{Pt}) / \pi(\mathrm{bhq}) /$ $\pi(p$-tol $\left.) \rightarrow \pi^{*}(\mathrm{bhq})\right]$. However, for complex 1c, the LLCT character $\left[\pi(p\right.$-tol $\left.) \rightarrow \pi^{*}(\mathrm{bhq})\right]$ is not present in the above-mentioned transitions. The cyclometalated organoplatinum(II) complex series of $\left[\mathrm{Pt}\left(p-\mathrm{XC}_{6} \mathrm{H}_{4}\right)(\mathrm{bhq})\left(\mathrm{PPh}_{2} \mathrm{Me}\right)\right], 2$, possess LC/MLCT $\left[\mathrm{d} \sigma(\mathrm{Pt}) / \pi(\mathrm{bhq}) \rightarrow \pi^{*}(\mathrm{bhq})\right]$ character in their emissive states. The small contribution of LLCT character $\left[\pi\left(p-\mathrm{XC}_{6} \mathrm{H}_{4}\right) / \pi(\mathrm{bhq}) \rightarrow\right.$ $\left.\pi^{*}(\mathrm{bhq})\right]$ is observed for the $2 \mathrm{a}\left(\mathrm{Ar}=\mathrm{C}_{6} \mathrm{H}_{5}\right)$ and $2 \mathbf{e}\left(\mathrm{Ar}=p-\mathrm{MeC}_{6} \mathrm{H}_{5}\right)$ complexes lying relatively close to the lowest triplet. However, for complexes $\mathbf{2 b - 2 d}$ there is no observable ligand to ligand charge transfer in their lowest-energy triplet state. The presence of thermally accessible low-lying LLCT $\left[\mathrm{p}(\mathrm{X}) \rightarrow \pi^{*}(\mathrm{bhq})\right]$ states, (X $\left.=\mathrm{CF}_{3} \mathrm{CO}_{2}, \mathrm{Cl}, \mathrm{I}\right)$ in the cyclometalated organoplatinum(II) complex series of $\left[\mathrm{Pt}(\mathrm{bhq}) \mathrm{X}\left(\mathrm{PPh}_{2} \mathrm{Me}\right)\right], 3$, indicates that the population of LLCT character (excitation energies 2.63, 2.7 and $1.9 \mathrm{eV}$ for $\mathbf{3 a}, \mathbf{3 b}$ and $\mathbf{3 c}$ respectively) could be responsible for the low quantum yield values caused by nonradiative deactivation at $298 \mathrm{~K}$. In this series, complex 3c has the lowest-lying LLCT state and consequently the lowest quantum yield. In contrast, similar states are significantly higher in energy for complex $2 \mathrm{a}(3.36 \mathrm{eV})$, exhibiting its more efficient emissions at $298 \mathrm{~K}$.

\section{Conclusions}

Three series of cyclometalated organoplatinum(II) complexes were synthesized and fully characterized using multinuclear NMR spectroscopy and X-ray crystallography. By systematically modifying different kinds of ancillary ligands and changing the substituents on them, the effect of each part on their luminescence properties was studied.

The UV-vis transitions of the studied complexes are comparable to those reported for the complexes $\left[\mathrm{Pt}\left(p-\mathrm{MeC}_{6} \mathrm{H}_{4}\right)(\mathrm{bhq})\left(\mathrm{SMe}_{2}\right)\right]$, showing that ${ }^{1} \mathrm{LC}$ transitions within the bhq cyclometalated ligand $\left(\pi-\pi^{*}\right)$ are dominating. The lowest-energy band in the cyclometalated organoplatinum(II) complexes of series $\left[\mathrm{Pt}\left(p-\mathrm{MeC}_{6} \mathrm{H}_{4}\right)\right.$ (bhq)(L)], 1, comprises LLCT, MLCT and LC transitions that show slight dependence on the nature of the phosphine ligands. The complexes series $\left[\mathrm{Pt}\left(p-\mathrm{XC}_{6} \mathrm{H}_{4}\right)(\mathrm{bhq})\left(\mathrm{PPh}_{2} \mathrm{Me}\right)\right], 2$, have MLCT and LC transitions, although complexes $2 \mathrm{c}$ and $2 \mathrm{e}$ have an additional LLCT transition. The maxima of the complexes series $\left[\mathrm{Pt}(\mathrm{bhq}) \mathrm{X}\left(\mathrm{PPh}_{2} \mathrm{Me}\right)\right], 3$, show minor changes with the variation of anionic ligands indicating that they arise mostly from ${ }^{1} \mathrm{LC}(\mathrm{bhq})$ transitions, although the slopes of the lowestenergy maxima slightly shift to lower energies according to the $\pi$-donating ability of the $\mathrm{X}$ ligands.

Investigations of the photophysical properties of the three series of cyclometalated organoplatinum(II) complexes indicated that these complexes are emissive in the solid state with the lifetimes being on the order of $\mu \mathrm{s}$. Varying the ancillary ligands in the studied cycloplatinated complexes (i.e. phosphines, anionic, and aryls) shows an effect on the shape or energy of the emission bands; also they have an influence on the emission intensities at room temperature. The structured bands in the normalized emission spectra of the cyclometalated organoplatinum(II) complexes indicate the presence of a large amount of ligand-centered LC/MLCT (L = bhq) character in the emissive excited state, confirming that the emissions originate from the cyclometalated moiety $\operatorname{Pt}\left(\mathrm{C}^{\wedge} \mathrm{N}\right)$. Furthermore, our calculations suggest that transitions in the cyclometalated organoplatinum(II) complexes are a function of the aromatic ligand, degree of aromaticity, and attached electron donor/acceptor groups.

\section{Conflicts of interest}

There are no conflicts to declare.

\section{Acknowledgements}

Financial support from Shiraz University is gratefully acknowledged. Also MGH is thankful for the financial support of the Iran National Science Foundation (grant no. 94010886) and the support of Shahid Beheshti University Research Councils.

\section{References}

1 S. W. Botchway, M. Charnley, J. W. Haycock, A. W. Parker, D. L. Rochester, J. A. Weinstein and J. G. Williams, Proc. Natl. Acad. Sci. U. S. A., 2008, 105, 16071-16076.

2 E. Baggaley, J. A. Weinstein and J. G. Williams, Coord. Chem. Rev., 2012, 256, 1762-1785.

3 X. Mou, Y. Wu, S. Liu, M. Shi, X. Liu, C. Wang, S. Sun, Q. Zhao, X. Zhou and W. Huang, J. Mater. Chem., 2011, 21, 13951-13962.

4 M. Jamshidi, M. Babaghasabha, H. R. Shahsavari and S. M. Nabavizadeh, Dalton Trans., 2017, 46, 15919-15927.

5 M. Jamshidi, S. M. Nabavizadeh, H. Sepehrpour, F. N. Hosseini, R. Kia and M. Rashidi, J. Lumin., 2016, 179, 222-229. 
6 M. Jamshidi, S. M. Nabavizadeh, H. R. Shahsavari and M. Rashidi, RSC Adv., 2015, 5, 57581-57591.

7 C. A. Craig and R. J. Watts, Inorg. Chem., 1989, 28, 309-313.

8 H. Yersin, P. Huber and H. Wiedenhofer, Coord. Chem. Rev., 1994, 132, 35-42.

9 L. Chassot and A. Von Zelewsky, Inorg. Chem., 1987, 26, 2814-2818.

10 S. Jamali, S. M. Nabavizadeh and M. Rashidi, Inorg. Chem., 2008, 47, 5441-5452.

11 A. Zucca, G. L. Petretto, S. Stoccoro, M. A. Cinellu, M. Manassero, C. Manassero and G. Minghetti, Organometallics, 2009, 28, 2150-2159.

12 J. S. Owen, J. A. Labinger and J. E. Bercaw, J. Am. Chem. Soc., 2004, 126, 8247-8255.

13 S. M. Nabavizadeh, M. G. Haghighi, A. R. Esmaeilbeig, F. Raoof, Z. Mandegani, S. Jamali, M. Rashidi and R. J. Puddephatt, Organometallics, 2010, 29, 4893-4899.

14 M. G. Haghighi, S. M. Nabavizadeh, M. Rashidi and M. Kubicki, Dalton Trans., 2013, 42, 13369-13380.

15 A. Esmaeilbeig, H. Samouei, S. Abedanzadeh and Z. Amirghofran, J. Organomet. Chem., 2011, 696, 3135-3142.

16 B. Shafaatian, A. Akbari, S. M. Nabavizadeh, F. W. Heinemann and M. Rashidi, Dalton Trans., 2007, 4715-4725, DOI: 10.1039/ B708769A.

17 F. Julia, M.-D. García-Legaz, D. Bautista and P. GonzálezHerrero, Inorg. Chem., 2016, 55, 7647-7660.

18 M. J. Frisch, N. Rega, G. A. Petersson, G. W. Trucks, H. Nakatsuji, M. Hada, M. Ehara, K. Toyota, R. Fukuda, J. Hasegawa, M. Ishida, J. C. Burant, T. Nakajima, Y. Honda, O. Kitao, H. B. Schlegel, H. Nakai, M. Klene, X. Li, J. E. Knox, H. P. Hratchian, J. B. Cross, J. M. Millam, V. Bakken, C. Adamo, J. Jaramillo, R. Gomperts, G. E. Scuseria, R. E. Stratmann, O. Yazyev, A. J. Austin, R. Cammi, C. Pomelli, S. S. Iyengar, J. W. Ochterski, P. Y. Ayala, K. Morokuma, G. A. Voth, P. Salvador, M. A. Robb, J. J. Dannenberg,
V. G. Zakrzewski, S. Dapprich, A. D. Daniels, J. Tomasi, M. C. Strain, O. Farkas, D. K. Malick, A. D. Rabuck, K. Raghavachari, J. B. Foresman, J. R. Cheeseman, J. V. Ortiz, Q. Cui, A. G. Baboul, V. Barone, S. Clifford, J. Cioslowski, B. B. Stefanov, G. Liu, A. Liashenko, P. Piskorz, I. Komaromi, J. A. Montgomery Jr, R. L. Martin, D. J. Fox, B. Mennucci, T. Keith, M. A. Al-Laham, C. Y. Peng, A. Nanayakkara, M. Challacombe, P. M. W. Gill, B. Johnson, W. Chen, T. Vreven, M. W. Wong, M. Cossi, C. Gonzalez, J. A. Pople, K. N. Kudin and G. Scalmani, Gaussian 03, Revision C.02, 2004. 19 P. J. Hay and W. R. Wadt, J. Chem. Phys., 1985, 82, 270-283. 20 M. Cossi, G. Scalmani, N. Rega and V. Barone, J. Chem. Phys., 2002, 117, 43-54.

21 V. Barone, M. Cossi and J. Tomasi, J. Chem. Phys., 1997, 107, 3210-3221.

22 P. S. Hanley and J. F. Hartwig, J. Am. Chem. Soc., 2011, 133, 15661-15673.

23 S. Bhargava, K. Kitadai, T. Masashi, D. W. Drumm, S. P. Russo, V. W.-W. Yam, T. K.-M. Lee, J. Wagler and N. Mirzadeh, Dalton Trans., 2012, 41, 4789-4798.

24 E. Glendening, A. Reed, J. Carpenter and F. Weinhold, NBO Version 3.1, Gaussian, Inc., Wallingford, CT, 2004, included in Gaussian03.

25 Rigaku Oxford Diffraction, CrysAlisPro, Version 1.171.38.37b, 2015.

26 L. Palatinus and G. Chapuis, J. Appl. Crystallogr., 2007, 40, 786-790.

27 V. Petříček, M. Dušek and L. Palatinus, Z. Kristallogr. - Cryst. Mater., 2014, 229, 345-352.

28 M. G. Haghighi, M. Rashidi, S. M. Nabavizadeh, S. Jamali and R. J. Puddephatt, Dalton Trans., 2010, 39, 11396-11402.

29 S. M. Nabavizadeh, H. R. Shahsavari, M. Namdar and M. Rashidi, J. Organomet. Chem., 2011, 696, 3564-3571.

30 R. B. Aghakhanpour, S. M. Nabavizadeh, M. Rashidi and M. Kubicki, Dalton Trans., 2015, 44, 15829-15842. 